\title{
CRESCIMENTO, COEFICIENTE DE DIGESTIBILIDADE DA MATÉRIA SECA, CONCENTRAÇÃO E EXTRAÇÃO DE NUTRIENTES PELO D anicum maximum JACQ. CV. MAKUENI DOS 30 AOS 180 DIAS DE IDADE.
}

OSCARLINA LÚCIA DOS SANTOS WEBER

Orientador: Prof. Dr. HENRIQUE PAULO HAAG

Dissertação apresentada à Escola

Superior de Agricultura "Luiz de Queiroz", da Universidade de São Paulo, para obtenção do título de Mestre em Agronomia. Área de concentração: Solos $\theta$ Nutrição de Plantas.

PIRACICABA

Estado de São Paulo - Brasil

Agosto, 1984 
i $i j$.

Aos meus pais

PAULO

CANDIDA MARIA

Ao meu esposo

EDUARDO

pelo reconhecimento, apoio e pela paciência.

DEDICO. 


\section{AGRADECIMENTOS}

Ao Professor Doutor Henrique Paulo Hag, pela orientação, de dicação e amizade dispensadas.

Ao Dr. Fábio Teotónio Teixeira de Oliveira, chefe da Fazenda Canchim, Unidade de Execução da Pesquisa de Âmbito Es tadual de São Carlos - SP, pela colaboração na realiza ção do presente trabalho.

Aos funcionārios da Area Experimental da Fazenda Canchim (UEPAE São Carlos, SP) pela colaboração na realização do presen te trabalho.

Aos funcionārios do Setor de Nutrição Mineral de Plantas, do Departamento de Química da ESALQ/USP.

A Escola Superior de Agricultura "Luiz de Queiroz" - USP, pelo oferecimento do Curso, pela contribuição e formação científica e cultural.

A Universidade Federal de Mato Grosso, Centro de Ciencias Agrárias - Departamento de Agronomia, pela oportunidade oferecida à realização do curso.

A todos que direta ou indiretamente contribuiram para óx $\underline{\mathbf{i}}$ to deste trabalho. 
Pāgina

RESUMO $\ldots \ldots \ldots \ldots \ldots \ldots \ldots \ldots \ldots \ldots \ldots \ldots \ldots \ldots \ldots \ldots \ldots \ldots \ldots \ldots$ $x$

SUMMARY $x i j i$

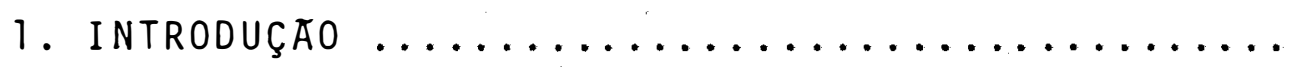

2. REVISÁO de literatura ................. 7

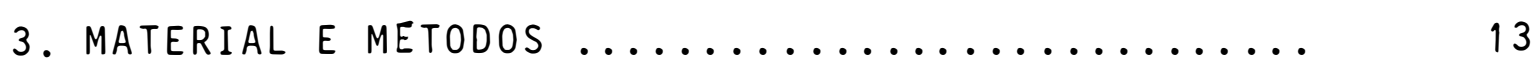

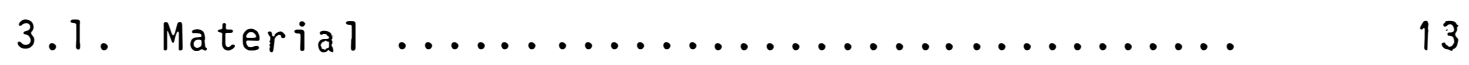

3.2. Métodos $\ldots \ldots \ldots \ldots \ldots \ldots \ldots \ldots \ldots \ldots \ldots \ldots$

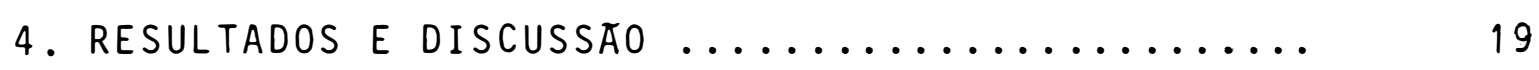

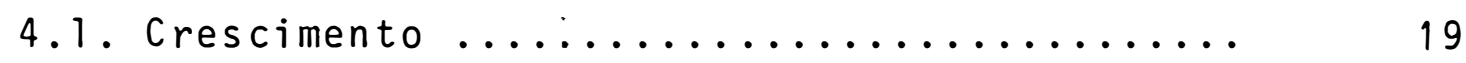

4.2. Digestibilidade in vitro da matéria seca... 23

4.3. Concentração e acumulação de nutrientes ... 27

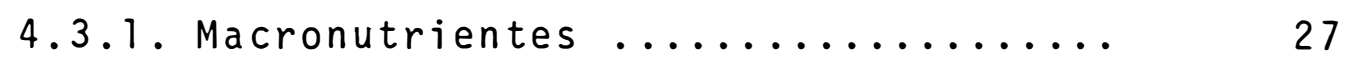

4.3 .1 .1$. Nitrogēnio $\ldots \ldots \ldots \ldots \ldots \ldots . \ldots \ldots$

4.3 .1 .2 . Fósforo $\ldots \ldots \ldots \ldots \ldots \ldots \ldots, 31$

4.3 .1 .3 . Potássio $\ldots \ldots \ldots \ldots \ldots \ldots \ldots . \ldots \ldots$

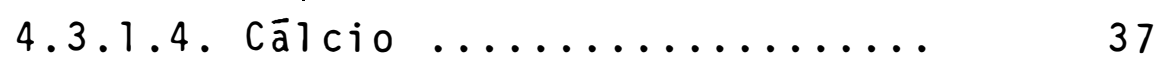

4.3 .1 .5 . Magnēsio ............ 40

4.3 .1 .6 . Enxofre ............ 43

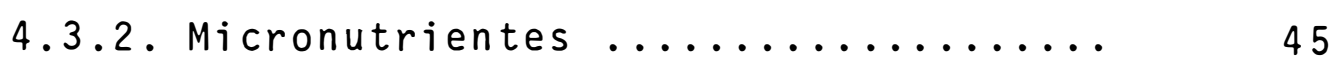

4.3 .2 .1 . Cobre ............................ 45

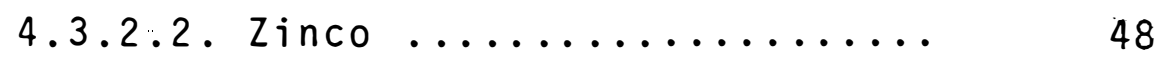

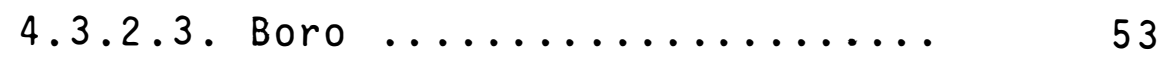

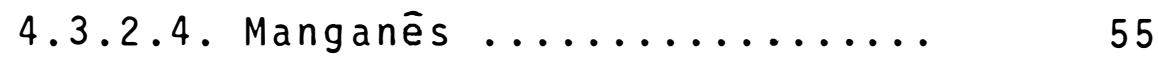

4.3.2.5. Ferro ............. 59 


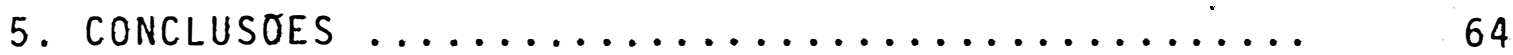

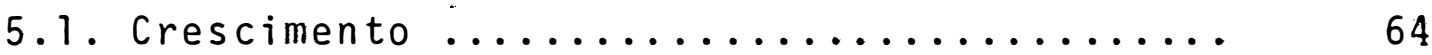

5.2. Coeficiente de digestibilidade da matéria se

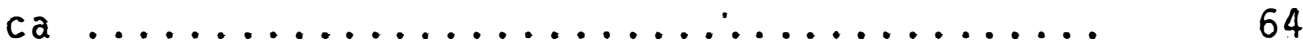

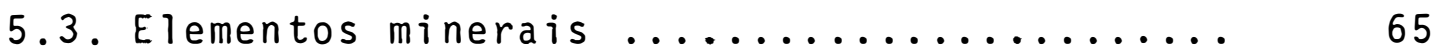

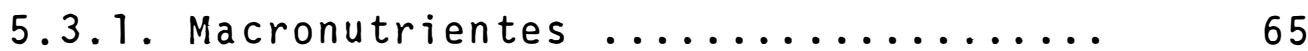

5.3 .1 .1 . Concentração ........... 65

5.3 .1 .2 . Aсйmulo ............. 65

5.3.2. Micronutrientes ............... 65

5.3.2.1. Concentração .......... 66

5.3.2.2. Acūmu $10 \ldots \ldots \ldots \ldots \ldots 66$

5.4. Exportação máxima de nutrientes correspon dendo a $1.425 \mathrm{~kg}$ por hectare de matéria seca aos 120 dias de idade ............... 66

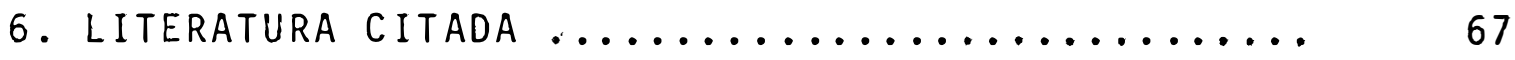




\section{LISTA DE TABELAS}

TABELA NQ

Pāgina

1

Diferenças botānicas entre sete capins

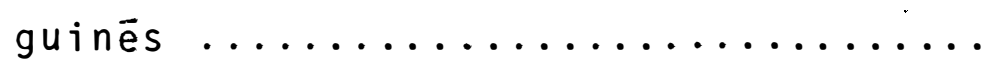

2

Peso da matéria seca $\left(\mathrm{g} / \mathrm{m}^{2}\right)$ de Panicum maximum cv. Makueni em função da $i d a-$

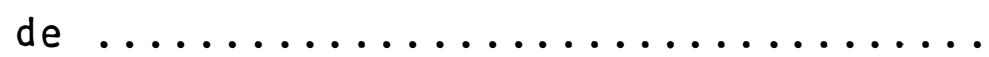

Porcentagem de digestibilidade in vitro da matéria seca em função da ida-

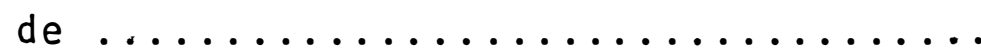

4 Concentração e acūmulo dos macronutrientes na planta inteira de Panicum maximum Jacq. 'cv. Makueni em função da

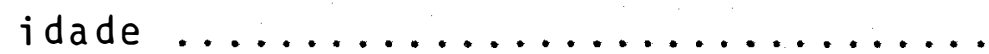

Concentração e acūmulo dos micronutrientes na planta inteira de Panicum maximum Jacq. cv. Makueni em função da

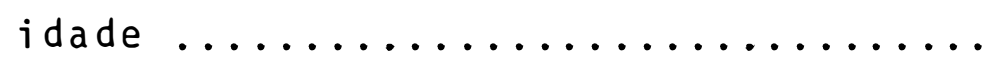




\section{LISTA DE FIGURAS}

FIGURA NO

Pāgina

1 Curva e equação de regressão do peso da matéria seca (\%) da planta inteira de Panicum maximum Jacq. cv. Makueni, em função da idade .................

Coeficiente de digestibilidade in vitro da matēria seca de Panicum maximum Jaca. cv. Makueni em função da idade ........

Concentração e acūmulo de nitrogēnio da planta inteira de Panicum maximum Jacq. cv. Makueni em função da idade ........

Concentração e acūmulo de fōsforo da planta inteira de Panicum maximum Jacq. cv. Makueni, em função da idade .......

5

Concentração e acūmulo de potássio da planta inteira de Panicum maximum Jaca. cv. Makueni, em função da idade ......

6

Concentração e acūmulo de cālcio da plạn ta inteira de Panicum maximum Jacq. cv. Makueni, em função da idade ......

7 Concentração e acūmulo de magnésio da planta inteira de Panicum maximum Jacq. cv. Majueni, em função da idade ......

Concentração e acūmulo de enxofre da planta inteira de Panicum maximum Jacq. cv. Makueni, em função da idade ....... 
9

Concentração e acúmulo de cobre da plan ta inteira de Panicum maximum Jacq. cv. Makueni em função da idade .......

10

Concentração e acūmulo de zinco da planta inteira de Panicum maximum Jacq. cv. Makueni, em função da idade ......

11 Concentração e acūmulo de boro da planta inteira de Panicum maximum Jacq. cv. Makueni, em função da idade .....

12 Concentração e acūmulo de manganēs da planta inteira de Panicum maximum Jacq. cv. Makueni, em função da idade ......

13 Concentração e acūmulo de ferro da planta inteira de Panicum maximum Jacq. cv. Makueni, em função da idade ...... 
CRESCIMENTO, COEFICIENTE DE DIGESTIBILIDADE DA MATERIA SECA, CONCENTRACAO E EXTRACAO DE NUTRIENTES PELO Panicum maximum, JACQ. CV. MAJUENI, DOS 30 AOS 180 DIAS DE IDADE.

Candidata: OSCARLINA LOCIA DOS SANTOS WEBER orientador: Prof. Dr. HENRIQUE PAULO HAAG

\section{RESUMO}

A graminea Panicum maximum c.v. Makueni foi es tudada com a finalidade de se avaliar o crescimento, atravēs da producão de matéria seca, o coeficiente de digestibilidade in vitro da matéria seca e a concentração e extração de ma-: cro e micronutrientes em função da idade. Foi conduzido um en saio de campo na Fazenda Canchim (UEPAE, de São Carlos - EMBRAPA), São Carlos - SP, em solo Latossolo Vermelho Amarelo, fase arenosa em ārea de pasto Makueni jā formado e rebaixado. A ārea foi adubada com nitrogēnio correspondendo a $250 \mathrm{~kg}$ de sulfato de amōnio por hectare. A intervalos de 30 dias após o rebaixamento até aos 180 dias, colhiam-se ao acaso quatro metros quadrados das plantas sem subdividir em folhas e caules. No material coletado foi determinado o peso* de matéria seca, o coeficiente de digestibilidade in vitro, bem como procedeu-se à anālise quantitativa de macro e micronutrientes. 0 del 1 neamento experimental foi o inteiramente casualizado com quatro repeticões para as determinacões do peso de matéria seca e dos nutrientes, e com duas repetições para o coeficiente de digestibilidade.

* Utilizou-se peso em vez de massa por ser mais comum. 
As principais conclusões são as seguintes:

- A produção de matéria seca é mäxima aos 120 dias, com $1425 \mathrm{~kg} / \mathrm{ha}$.

- A maior velocidade de acūmulo de matéria seca ocorre próximo aos 60 dias após o rebaixamento.

- o coeficiente de digestibilidade da matéria seca é máximo aos 30 dias com $51,9 \%$ e decresce linearmente, a tingindo aos 180 dias $29,4 \%$.

- A concentração de nitrogẽnio ē máxima aos 30 dias com $1,62 \%$ e minima aos 120 dias com 0,72\%.

- A concentração de fósforo é máxima aos 180 dias com $0,87 \%$ e mínima aos 60 dias com 0,003\%.

- A concentração de potássio é linear com as idades variando de $2,8 \%$ na fase inicial a $0,76 \%$ aos 180 dias.

- A concentração de cālcio é máxima aos

dias com $0,53 \%$.

- Não hã variação na concentração de magnēsio em função da idade da planta.

- A concentração de enxofre varia de $0,14 \%$ aos 30 dias para um minimo aos 120 dias com 0,07\%.

- A concentração de cobre é mais elevada aos 30 dias com $7,63 \mathrm{ppm}$.

- A concentração de zinco é máxima aos 180 dias com 22,66 ppm e mínima aos 120 dias com 12,42 ppm.

- A concentração de boro é máxima aos 150 dias com 11,76 ppm e minima aos 60 dias com 1,69 ppm. 
- A concentração de manganês é máxima aos 180 dias com 133,85 ppm e minima aos 30 dias com 49,64 ppm.

- A concentração de ferro é máxima aos 180 dias com 236,25 ppm e minima aos 90 dias com 136,22 ppm.

- 0 acūmulo de fósforo, potássio, cálcio e cobre é máximo aos 90 dias.

- 0 acūmulo de magnésio é máximo aos 120 dias.

- 0 acūmulo de enxofre é máximo aos 60 dias.

- 0 acúmulo de zinco e ferro não diferiu nas diferentes idades.

- 0 acūmulo de boro e manganês é máximo aos 180 dias.

- A exportação de nutrientes contida na produção māxima de $1425 \mathrm{~kg}$ de matēria seca por hectare obedece à seguinte rrúem: jotássio - $30,4 \mathrm{~kg}$; nitrogēnio - 13,9 kg; cál cio - $7,0 \mathrm{~kg}$, magnésio - $6,3 \mathrm{~kg}$; enxofre - $1,3 \mathrm{~kg}$; fósforo $1,2 \mathrm{~kg}$; ferro - $286 \mathrm{~g}$; manganês - $157 \mathrm{~g}$; zinco - $23 \mathrm{~g}$; boro $13,2 \mathrm{~g}$ e cobre $-7,6 \mathrm{~g}$. 
GROWTH, DIGESTIBILITY COEFICIENT OF DRY MATTER, CONCENTRATION AND CONTENT OF NUTRIENTS BY Panicum maximum, JACQ. CV. MAKUENI FROM 30 TO 180 DAYS AGE

Candidate: OSCARLINA LOCIA DOS SANTOS WEBER Adviser: Prof. Dr. HENRIQUE PAULO HAAG

\section{SUMMARY}

Makueni being a promissing. specie for Brazilian cattle raising, the present work was carried out to determine:

1) Weight of the dry matter produced

2) Coeficient of dry matter digestibility;

3 ) Concentration and accumulation of macro and micronutrients from 30 days after cutting the grass up to 180 days old.

For the purpose an area comprising $600 \mathrm{~m}^{2}$ of Latossolo Vermelho Amarelo (0xisol) at São Carlos, State of São Paulo, Brazil on the farm Canchim, research institute which belongs to EMBRAPA, the trial was conducted the meadow was cut and fertilized with ammonium sulphate at the rate of 250 $\mathrm{kg} / \mathrm{ha}$. At intervals of 30 days after the cutting up to 180 days plants corresponding to one square metre were collected. The dry matter content was determined and the material was analysed for $\mathrm{N}, \mathrm{P}, \mathrm{K}, \mathrm{Ca}, \mathrm{Mg}, \mathrm{S}, \mathrm{B}, \mathrm{Cu}, \mathrm{Fe}, \mathrm{Mn}$ and $\mathrm{Zn}$ content. The coeficient of digestibility was determined in vitro. 
$x i v$.

The following conclusions may be draw.

The dry matter production is greatest at 120 days with a production of $1,425 \mathrm{~kg} / \mathrm{ha}$.

The fasted dry matter.production occurs around the 60 days after cutting the meadow.

The coeficient of digestibility is high at 30 days with $51.9 \%$ and 1 owers to $29.4 \%$ with on days.

The concentration of $\mathrm{N}$ is high at the 30 days $(1.62 \%)$ and lowest at the 120 days $(0.72 \%)$.

The concentration of $P$ is highest at the 120 days $(0.87 \%)$ and lowest at the 60 days $(0.003 \%)$.

The concentration of $k$ is linear with the age of the grass. The concentrations of $K$ change from $2.8 \%$ at the begining to $0.76 \%$ after 180 days.

The concentration of $\mathrm{Ca}$ is highest at the 90 days $(0.53 \%)$.

There are not variation in the concentration of Mg in function with the age of the grass.

The concentration of $S$ change of $0.14 \%$ at the 30 days for a lowest at the 120 days $(0.07 \%)$.

The concentration of $\mathrm{Cu}$ is highest at the 30 days $(7.63 \mathrm{ppm})$.

The concentration of $\mathrm{Zn}$ is highest at the 180 days $(22.66 \mathrm{ppm})$ and lowest at the 120 days $(12.42 \mathrm{ppm})$.

The concentration of $B$ is highest at the 150 days $(11.76 \mathrm{ppm})$ and lowest at the 60 days $(1.69 \mathrm{ppm})$. 
The concentration of $M n$ is highest at the 180 days (133.8 ppm) and lowest at the 30 days (49.6 ppm).

The concentration of $\mathrm{Fe}$ is highest at the 180 days $(236.25 \mathrm{ppm})$ and lowest at the 30 days $(49.6 \mathrm{ppm})$.

The accumulation of $\mathrm{P}, \mathrm{K}, \mathrm{Ca}$ and $\mathrm{Cu}$ is highest at the 90 days.

The accumulation of $\mathrm{Mg}$ is highest at the 120 days and Saccumuled the highest amounts at the 60 days.

The accumulation of $\mathrm{Zn}$ and Fe did not differ with the age of the grass.

The accumulation of $B$ and $M n$ is highest at the 180 days.

The greatest amounts of nutrients content in $1,425 \mathrm{~kg} / \mathrm{ha}$ of dry matter obey the following order:

$$
\begin{aligned}
& \mathrm{K}-30.4 \mathrm{~kg} ; \mathrm{N}-13.9 \mathrm{~kg} ; \mathrm{Ca}-7.0 \mathrm{~kg} \\
& \mathrm{Mg}-6.3 \mathrm{~kg} ; \mathrm{S}-1.3 \mathrm{~kg} ; \mathrm{P}-1.2 \mathrm{~kg} . \\
& \mathrm{Fe}-286 \mathrm{~g} ; \mathrm{Mn}-157 \mathrm{~g} ; \mathrm{Zn}-23 \mathrm{~g} ; \mathrm{B}-13.2 \mathrm{~g} ; \\
& \mathrm{Cu}-7.6 \mathrm{~g} .
\end{aligned}
$$




\section{INTRODUÇAO}

Visando ampliar as fontes de proteínas na dieta alimentar do homem, como também contribuir com o desenvolvi mento das ciēncias agronómicas, novas pesquisas se fazem necessārias no campo da nutrição mineral das pastagens e consequentemente na alimentação dos animais. Os países latino ameri canos, inclusive o Brasil, têm uma população bovina maior que o da América do Norte, Europa Ocidental e Africa Tropical (C.I.A.T.-Colómbia, 1978).

A exploração pecuāria na sua maioria se concen tra em solos tropicais SANCHEZ e ISBELL (1982) afirmam que 884 milhões de hectares da América Tropical, correspondentes a $58 \%$ de suas āreas, são constituídas de oxissolos e ultissolọ. Estes tipos de solos caracterizam-se por serem altamente lixi viados, comumente deficientes em bases, elevada acidez, baixa disponibilidade de $N, P, S$ e alta concentração de Al e Mn tro cāveis. Ademais, estes solos possuem alta capacidade de fixa ção de fōsforo e deficiēncia em $Z n$, Cu e Mo, constituindo-se nos principais fatores limitantes do crescimento das forragei ras. 
No Brasil estes tipos de solos predominam e as ăreas de pastagens ocupam aproximadamente 147 milhões de hectares, sendo que $73 \%$ naturais e $27 \%$ cultivadas. As pastagens naturais constituem a base para a alimentaça do gado na América Latina,e geralmente, são a ūnica fonte de àlimento para o gado no Brasil, principalmente na região centro-sul (GOMIDE et alii, 1969 e SEMPLE, 1970). A população bovina no Brasil cresceu de 73 milhões em 1960 para cerca de 149 milhões de ca beças em 1982, situando-se numa posicão de destaque no contex to da pecuária mundial, sendo superada em niveis globais somente pela India, Estados Unidos e União Soviética (HAAG et alii, 1984).

A pecuāria brasileira, embora contando com 149 milhões de cabeças no seú rebanho bovino, apresenta baixo indice de produtividade e baixa capacidade de suporte das pastagens. Estas pastagens durante o periodo de seca, devido aos aspectos qualitativos e quantitativos da forragem, são incapazes de manter o peso vivo dos animais que nelas se encontram em pastejo. Para que esses fatores i imitantes sejam superados, a introdução de pastagens cultivadas se fez necessäria. Dentro das pastagens, as gramineas possuem uso tradicio nal e bastante divulgado na atividade pecuāria. 
As gramineas de maior importância são as tropi cais, originārias da Africa, na região compreendida entre o Equador e o Trópico de Capricōrnio. Dessa ārea tem surgido as espécies mais difundidas nos trópicos americanos, pois a variação genética tem permitido aos melhoristas um excelente tra balho. As gramineas introduzidas da Africa foram o colonião, elefante, quicuio, pangola, as braquiārias, rhodes e outros. As gramineas oriundas da América do Norte são poucas, e todas de menor valor nutritivo (Paspalum notatum, grama batatais; Paspalum dilatatum, grama comprida e outros Paspalum).

A introducão das primeiras gramineas na Amērica foi de maneira casual, através do trāfico de escravos da Guiné; nos navios que os conduziam, as acomodacões dos mesmos eram feitas com colonião, elefante e outros capins que depois eram jogados nas praias, quando chegavam ao Brasil.

De modo geral, as pastagens naturais e cultivadas são cobertas em sua maior extensão pelos capins colo nião, jaraguá e gordura, principalmente nas regiões de gadode corte; em menor escala, porém com frequēncia significativa,aparecem os pastos de pangola, braquiāria e estrela. Certas ca racteristicas gerais de clima, altitude e fertilidade de solos de diversas regiões do paîs, são agrupadas a fim de proporcionarem condições para que uma determinada forrageira dé melhores resultados do que outras. Para tanto, um zoneamento natural das pastagens do Brasil foi efetuado sendo reunido em quatro grandes grupos regionais, respeitando-se o critério 
de afinidade quanto às características climáticas, de altitude e de fertilidade do solo: Brasil subtropical. (Zonas fronteiricas entre sul de São Paulo e Paranā); Região centro-sul (Noroeste do Estado do Paraná e os Estados de São Paulo, Rio de Janeiro, Espirito Santo, Minas Gérais, Extremo Sul da Bahia, Goiás e Mato Grosso); Polígono das secas (Norte de Goiās e alguns campos de Mato Grossol e Amazōnia, Zona litorā nea e Recóncavo bahiano. Dentro desses grupos, a região centro-sul destaca-se por concentrar grande parte da ārea de cer rados, ārea de 82.359 .635 ha onde a pecuária de corte e leite sobressaem. (AGROCERES, 1982 e FIBGE, 1980).

o clima da região centro-sul é caracterizado por duas estacões distintas: a estacão das chuvas, quente e $\underline{\underline{u}}$ mida, intercaladas de estiagens quentes e secas, e o periodo de seca, com queda acentuada de temperatura, especialmente du rante as noites. Essas condicões climáticas influem desfavora velmente sobre o rendimento das pastagens, pois durante o perỉodo das águas há excesso de capim, mas seu aproveitamento nem sempre é viável. Entretanto, com a seca, a disponibilidade de alimento para o rebanho é reduzida, chegando a faltar durante 5 a 6 meses, o que resulta em producão de forragens com baixo valor nutritivo, reduzindo assim, a capacidade dos campos para atender às exigências nutricionais dos animais em pastejos.

A procura de forragens, adaptadas às situacões de solos tropicais é relativamente nova, devido princi- 
palmente ao fato de que a producão de pastagens nestes tipos de solos é bastante intensa. Com a expansão da fronteira agro pecuária, foram usados, sem grande éxito, esquemas de producão provados e bem sucedidos em outras áreas mais férteis ou com outros tipos de limitações; além disso, durante muitos anos as selecões de novos cultivares de plantas forrageiras eram feitas para ambientes sem as mesmas limitacões, especialmente adubos nitrogenados, quebra do ciclo extremado (excesso de capin nas águas e escassez na seca) e irrigacão (Jennings, 1976 citado por PORZECANSKI, 1982).

Tendo em vista ao exposto, uma nova cultivar de Panicum maximum entrou no contexto pecuário brasileiro, co. nhecido comercialmente como capim makueni. 0 capim colonião (Panicum maximum Jacq.) possui boas qualidades forrageiras que tem sido comprovados em nosso meio, participando com 11,22\% dos $36 \%$ das terras do Estado de São Paulo, com destaque na re gião noroeste (JARDIM et alii, 1962). Em levantamento mais re cente CARREIEL et alii. (1979) observaram que o colonião no Estado de São Paulo, concorre com $30 \%$ da área de pastagens ocupando 2.949 .050 ha.

A cultivar Makueni foi plantada primeiramente por J. Knight em Makueni, distrito do Kenya. Em 1962, ela foi levada à Estação Experimental de Kitale e multiplicada como K-6221. Dessa estação o Makueni foi introduzido na Austrália por J. Redrup e B. Grof em 1965. Em julho de 1974, foi libera do para comercialização, e recomendado como uma alternativapa 
ra outros capins "Guinēs" em terras baixas costeiras, ümidas e terras altas do trópico no norte da Queensland (MIDDLETON e MCCOSKER, 1975). Para MCCOSKER e TEITZEL (1975), Makueni pertence ao grupo dos "Guinés" que juntamente com Riversdale, Ha mil, Colonião, Embu e Guinea Coarse são mais produtivos em āreas tropicais de elevada precipitação. No Brasil, o Makueni foi introduzido em 1974 pela Brazisul Agropecuāria.Ltda., que forneceu as sementes ao Instituto de Zootecnia! de Nova Odessa, e em 1976 o IRI (IBEC Research'Institute) trouxe o Ma kueni da Austrālia e foi levado para a Estação Experimental de Matão. A distribuicão de capins do género Panicum è amplamente governada pela necessidade de elevadas temperaturas e uma precipitação maior que $1300 \mathrm{~mm}$; é muito sensivel à geada (Motta, 1953, citado por McCOSKER e TEITZEL, 1975). Makueni é uma cultivar que adapta relativamente com o inverno apresentando boa producão e no verão esta producão é satisfatōria (GROF e HARDING, 1970). Quanto aos solos, os capins "Guinés" são adaptados para uma série de solos (Motta, 1953 citado por MCCOSKER e TEITZEL, 1975), mas a producão é baixa em solos inférteis. Pouco conhecimento se tem quanto ao desempenho do Makueni submetido a solos de drenagem pobre (TEITZEL, ABBOTT e MELLOR, 1974b).

A finalidade deste estudo foi avaliar o cresc $\underline{i}$ mento, através da produção de matéria seca, o coeficiente de digestibilidade in vitro da matéria seca em função da idade e a extração de macro e micronutrientes durante o crescimentoem função da idade. 


\section{REVISAOO DE LITERATURA}

Antes de 1940, foi introduzido na Austrālia um grande número de gramineas para elevar a produtividade - das pastagens. No entanto, foi necessário fazer consorciaça com leguminosas para aumentar a produção de carne (HARDING, 1972). Tendo em vista a utilização das pastagens nos trópicos úmidos do norte da Queensland, HARDING (1972) avaliando a contribuicão da introducão de forragens para o desenvolvimento das pa tagens, testou novas cultivares de Panicum maximum ou de Brachiaria mutica em consorciação com um grupo promissor ... de. leguminosas tropicais. Entre as cultivares de Panicum maximum Jacq., estava ou foi incluida a cultivar Makueni, como CPI 37910, código este adquirido no Kenya, antes de ser introduzi do na Austrāila. Neste estudo, o autor determinou a produção de matéria seca (M.S.) em kg/ha/dia e verificou que o Makueni produziu $48 \mathrm{~kg}$ de M.S./ha/dia, enquanto que o colonião comum produziu $39 \mathrm{~kg} / \mathrm{ha} / \mathrm{dia}$. No verão, o capim Makueni mostrou-se superior ao colonião comum. 
GROF e HARDING (1970) estudando as produções de matéria seca e animal de Panicum maximum na costa tropical úmida no sul de Johnstone (Austrālia), utilizaram, comopa ràmetros: os diferentes numero de cortes, sistema de pastejos e tipo de adubação em dez cultivares de P. maximum (Hamil, colonião comum, Makueni, Q 37912, Q 8260, Q 8213*,CPI 37909 tipo 1 e 2) e Embu em consorciação com algumas leguminosas. No experimento de cortes, conduzido em duas estaçoes anuais (inverno e verão), foi fornecida uma quantidade de $224,17 \mathrm{~kg} / \mathrm{ano}$, $24,09 \mathrm{~kg} / \mathrm{ha} / \mathrm{ano}, 56,0425 \mathrm{~kg} / \mathrm{ha} / \mathrm{ano}$. Deste experimento foi obtida uma produção anual de matéria seca (M.S.) nas dez cultivares de $P$. maximum que variou de $15691,9 \mathrm{~kg} / \mathrm{ha}$ a 26900,4 $\mathrm{kg} / \mathrm{ha}$. Dos cinco cortes por ano, as cultivares Hamil, colonião, Q 8260, comum, Makueni e CPI 37912 não apresentaram diferencas significativas nas producões de M.S. $(27,55 \mathrm{~kg} / \mathrm{ha} / \mathrm{ano}$, $23,22 \mathrm{~kg} / \mathrm{ha} / a n o, 24,13 \mathrm{~kg} / \mathrm{ha} / \mathrm{ano} ; 24,25 \mathrm{~kg} / \mathrm{ha} / \mathrm{ano} ; 23,04 \mathrm{~kg} / \mathrm{ha} /$ ano e $22,49 \mathrm{~kg} / \mathrm{ha} / \mathrm{ano}$, respectivamente). A produção de matéria se ca foi afetada pela estação do ano e pelas cultivares. As cuI tivares mais altas Hamil e Colonião tiveram uma elevada produ ção de matéria seca durante o periodo chuvoso de verão. As cultivares de porte médio, em particular o Makueni, e para uma menor extensão o Embu e o Colonião comum, foram superio-

* No trabalho original as unidades utilizadas para as quantidades de nu trientes na adubação foram $1 \mathrm{~b} / \mathrm{ac} / \mathrm{ano}$.

Q - Queenland Department of Primary Industries Introduction Number. CPI - Commonweal th Plant Introduction Number. 
res aos tipos de maior porte na estação fria.

A cultivar Makueni manteve porcentagens médias de nitrogênio $(1,56 \%)$ e baixa de fósforo $(0,11 \%)$ em relação ao Embu; enquanto que as demais cultivares mantiveram baixas concentrações dos referidos nutrientes. No periodo de junho a setembro a cultivar Makueni mostrou crescimento superior às outras cultivares, incluindo Hamil e Colonião. A aplicação de nitrogênio foi mais eficiente na dosagem de $140 \mathrm{~kg} / \mathrm{ha} / \mathrm{ano}$, re sultando num incremento da produção de.16,921 kg de M.S./Kg de $N$ aplicado, com uma recuperação de $36 \%$ na capacidade da planta. Os autores verificaram que o Makuenié a cultivar que combina uma boa produção de inverno com uma razoável produção de verão.

BEID et alii (1973), em Uganda, determinaram a digestibilidade in vitro da matēria seca de gramineas tropicais em relação ao estádio de maturidade e verificaram que houve diferencas entre a digestibilidade das cultivares Makue ni e Embu, e que com a maturação da planta a digestibilidade diminuiu. Comparando o Embu com o Makueni, os autores obtiveram para as idades de 4, 8, 12 semanas os coeficientes de digestibilidade para o Embu foram de $74,8 \% ; 59,6 \%$ e $48,6 \%$, enquanto que os do Makueni foram de $60,5 \% ; 49,6 \% ; 49,8 \%$.

Em Johnstone, Austrālia, MIDDLETON e McCOSKER (1975) em um ano (1973-1974) obtiveram uma produção extremamente alta de matéria seca (mais que 60 ton/ha) tanto para 0 Makueni quanto para o colonião comum quando aplicaram $300 \mathrm{~kg} /$ 
ha de nitrogênio e foram submetidos a cortes em intervalos de 12 semanas a $10 \mathrm{~cm}$ do solo. Muitos autores relatam que elevadas produções de matéria seca no capim colonião eram obtidas com intervalos de cortes maiores, o que vem confirmar com os dados obtidos por MIDDLETON e McCOSKER (1975) onde um aumento no intervalo de amostragem de 3 semanas para 12 semanas aumentou a produção anual de matéria seca de $22,7 \mathrm{~kg} / \mathrm{ha}$ para $62,4 \mathrm{~kg} / \mathrm{ha}$ para o colonião comum, e de $23,3 \mathrm{~kg} / \mathrm{ha}$ para 62,5 $\mathrm{kg} / \mathrm{ha}$ para o capim Makueni.

Makueni apresenta caracteristicas semelhantes ao colonião comum, responde prontamente ao nitrogênio, quando ocorre deficiência deste elemento no solo. Quanto ao fósforo e potássio, segundo TEITZEL (1969a,b), o capim colonião co mum em resposta a esses elementos, teve uma elevada producão de matéria seca. Para uma aplicação de $72 \mathrm{~kg} P / h a$ o colonião comum mostrou um aumento de $261 \%$ na matéria seca e um aumento de $62 \%$ de matéria seca quando se aplicou $121 \mathrm{~kg}$ de $\mathrm{K} / \mathrm{ha}$.

MIDDLETON (1982), em experimento em Queensland, Austrālia, trabalhou com cinco g̣raminneas forrageiras: Panicum maximum cv. Makueni e comum; Setaria sphacelata var. Splendida, Digitaria decumbens e Brachiaria decumbens cv. Brasilisk, averiguou por um perīodo de 2 anos a producão de matéria seca e a concentracão de $N$ nesses capins. No primeiro ano, ficou regís trado que o efeito do corte à altura baixa $(10 \mathrm{~cm})$ na 12 a semana, houve com as duas variedades de Panicum maximum, uma producão elevada de matéria seca. Para o Makueni registrou 
40,72 t/ha enquanto para o colonião foi registrado 40,12 t/ha. No 20 ano, o corte na 12 a semana foi excluído e a menor altura foi processada a $5 \mathrm{~cm}$, o que ocasionou uma relativa queda na produção de matéria seca, com exceção do Makueni (17,09 t/ ha). Em termos de nitrogēnio, o autor observou que as concentracões médias da proteina bruta $(\% \mathrm{~N} \times 6,25)$ decresceram à me dida que os intervalos de cortes. foram aumentados; e a concen tração de nitrogênio foi mais elevada durante o periodo de me nor crescimento. Entre as gramineas es.tudadas, os capins Makueni (16,3 t de M.S./ha) e Setaria (15,8 t de M.S./ha tiveram uma elevada produtividade.

MIRANDA (1982), em estudo com capim Makueni em casa de vegetação, averiguou o efeito da adubação com diferen tes niveis de $N, P$ e $K$ sobre o crescimento e producão e ainda os niveis de nutrientes na composicão quỉmica dos tecidos em função dos nỉveis de adubação com N, P e K. Foi verificado que as produções de matéria seca dos caules e folhas foram afetadas pela aplicação de nitrogēnio no solo (200 mg/vaso). A ausēncia de potássio, e a dosagem máxima de fósforo (aproximada mente $165 \mathrm{mg} P /$ vaso), proporcionou um crescimento linear tanto nos caules quanto nas folhas. Em presença de potássio, a produção máxima estimada de matéria seca foi de: 5,54 g/vaso, com 104,08 mg/vaso de fósforo e $200 \mathrm{~g} /$ vaso de nitrogēnio, e de 4,74 g/vaso de M.S. com 107,12 mg/vaso de fósforo e $100 \mathrm{~g}$ de nitrogênio. 0 autor verificou através de interação que as . concentraçães de macro e micronutrientes foram afetadas pela aplicação de ni- 
trogēnio, fósforo e potássio. A aplicacão de nitrogēnio provo cou aumento nas concentrações de nitrogēnio, magnésio, enxofre, boro, manganēs e zinco nas plantas; jā a aplicação de fósforo elevou os teores de fósforo, cālcio, magnésio e enxofre nos tecidos, com dependēncia das aplicacões de nitrogēnio e potássio; o fornecimento de potássio aumentou as concentracões de potássio, enxofre, boro, cobre e zinco dos tecidos, e diminuiu a concentracão de fósforo. Os efeitos sofreram interacões com o fornecimento de fósforo e.nitrogēnio. 


\section{MATERIAIS E METODOS}

\subsection{Material}

0 ensaio sobre a marcha de absorcão de nutrien tes, foi conduzido na Fazenda Canchim (UEPAE de São Carlos EMBRAPA), no perīodo de dezembro de 1982 a junho de 1983.

A referida Unidade se localiza numa região cujo clima é do tipo Cwbi, segundo a classificação de Köeppen (1948), cujas características são de clima temperado chuvoso, com inverno seco e temperatura média do mês mais frio (junho) de $16,5^{\circ} \mathrm{C}$, a a do més mais quente (janeiro) de $21,5^{\circ} \mathrm{C}$. A precipitação média anual è de $1495 \mathrm{~mm}$, sendo o mês de julho o mais seco, com $27 \mathrm{~mm}$ de média e o de janeiro o mais chuvoso, com $260 \mathrm{~mm}$ de média. O perīodo de seca se estende de abril a setembro e o das āguas de outubro a março. Durante o período do experimento, a temperatura média registrada do mēs mais frio (junho) foi de $14,4^{\circ} \mathrm{C}$ e a do mês mais quente (fevereiro) de $27,9^{\circ} \mathrm{C}$. Quanto à precipitação média anual, foi registrado 


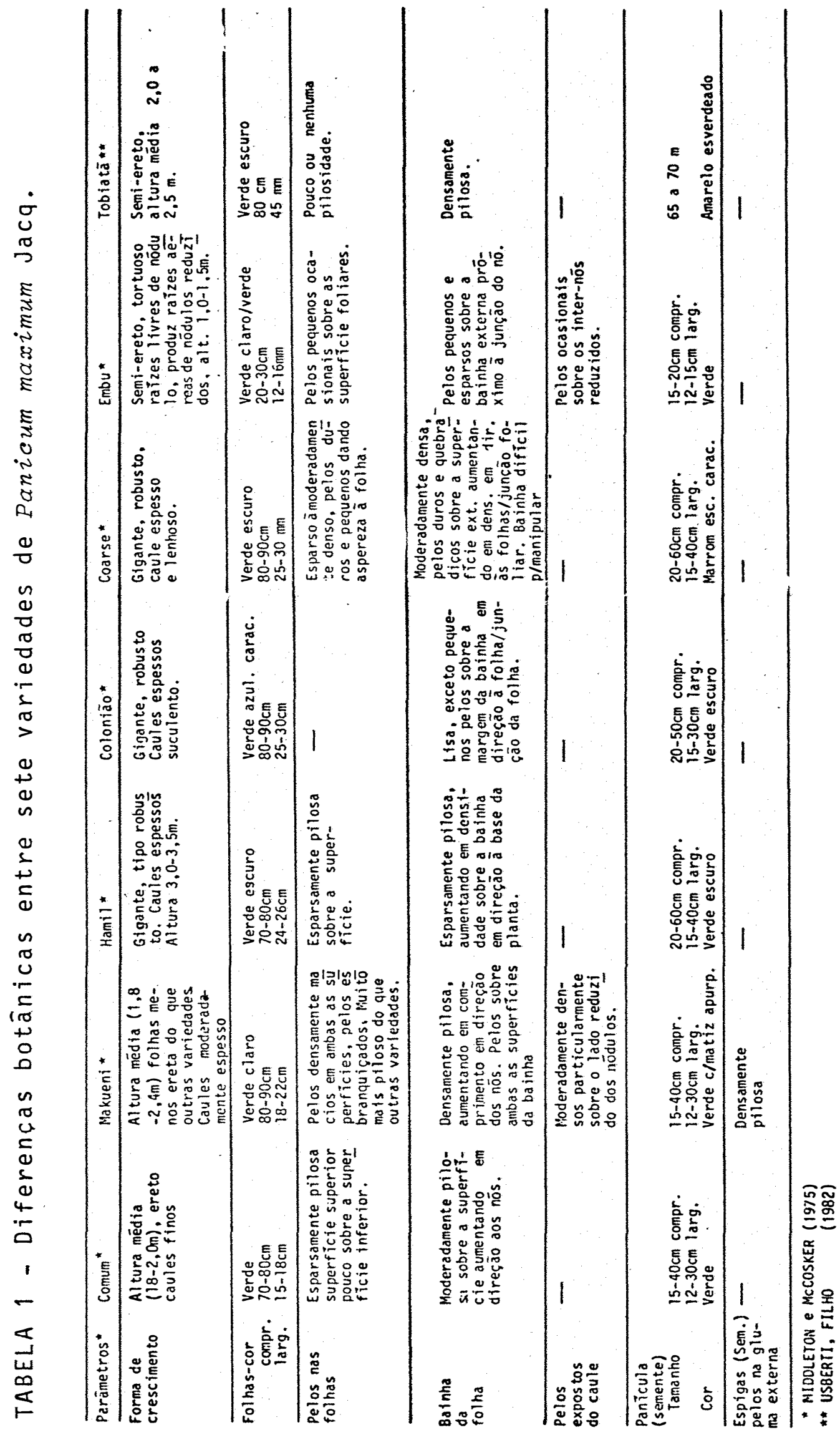


$2.386,2 \mathrm{~mm}$, sendo o mes de janeiro/83 o mais chuvoso, com $415,8 \mathrm{~mm}$ e o de julho/83 o mais seco com 52,4 mm.

\subsubsection{Solo e Espëcie Vegetal}

Segundo o Boletim do Servico Nacional de Pesquisas Agronómicas do Ministério da Agricultura (1960), os so los na ārea possuem caracteristicas de perfis latossōlicos, predominando o Latossolo Vermelho Amarelo (LVA), fase arenosa. As anālises quỉmicas do mesmo, realizadas no Laboratōrio de Quỉmica Agrīcola da Ultrafértil S.A. - Unidade Sumarë, apresentaram as seguintes caracteristicas quimicas: $\mathrm{pH}-5,9$, cá. (eq. $\mathrm{mg} / 100 \mathrm{ml}$ ) $-1,1, \mathrm{Mg}^{+2}$ (eq. $\left.\mathrm{mg} / 100 \mathrm{ml}\right)-0,9, \mathrm{Al}^{+3}$ (eq. $\mathrm{mg} / 100 \mathrm{ml})-0,0, P(\mu \mathrm{g} / \mathrm{ml})<3, \mathrm{~K}(\mu \mathrm{g} / \mathrm{ml})-32$ e $M .0(\%)-2,6$.

0 vegetal escolhido como planta teste foi o ca pim Makueni, que segundo a classificacão botānica dos sistemas Engler (1964) e Hitchcock (1971) citados por MITIDIERI, (1983) pertence à divisão Angiosperamae; classe Monocotyledonae; ordem Graminales; famîlia Graminae; sub-familia Panicoidae; tribo Panicea; gênero Panicum; espécie Panicum maximum Jacq; nome cientifico Panicum maximum c.v. Makueni.

Suas características para a classificacão de Bogdan (1955), citado por McCOSKER e TEITZEL (1975), é do tamanho médio (pequeno, folhas predominantemente basais, taludo e folhosol). Por conveniência prática de distinguir os principais tipos de "Guiné" da Queensland, MIDDLETON e : McCOSKER (1975) listaram as diferenças morfológicas que são reproduzi- 
das na tabela 1. Vale ressaltar que na tabela 1 foi incluida a cultivar Tobiatã que pertence à espécie do Panicum maximum (USBERTI FILHO, 1982).

\subsection{Métodos}

a) Tratamentos

Os tratamentos, seis épocas de amostragem e quatro repeticões foram montadas num delineamento inteiramente casualizado.

\section{b) Instalação do Ensaio}

b.1. Aspecto da ārea em estudo.

Antes da instalaça do experimento, as plantas encontravam-se bastante amareladas, em alguns pontos havia presença de grama batatais no stand e devido à fenacão seguido de periodo seco, as plantas estavam depauperadas.

b.2. 0 ensaio iniciou-se em 14/12/82, em ārea de pasto de Makueni já formado, dentro da qual foram isolados $600 \mathrm{~m}^{2}$ e procedeu-se a um rebaixamento prévio do referido capim, sendo fornecido uma dose suplementar de nitrogēnio com sulfato de amōnio, correspondendo à $250 \mathrm{~kg}$ do adubo por hecta re conforme CORSI (1975). Segundo o autor, a adubação nitrogenada possibilita crescimento mais rápido e maior producāo de M.S., o que permite maior frequéncia de cortes e um material de maior digestibilidade. 


\section{c) Colheita}

0 primeiro corte da graminea foi efetivado aos 30 dias após o rebaixamento, procedendo-se ao corte das plantas rente ao solo, sendo repetidos esta operação aos 60, 90, 120; 150 e 180 dias de idade, totalizando seis cortes.

A amostragem foi efetuada ao acaso, com quatro repeticões, utilizando-se de uma armação de madeira de um metro quadrado $\left(1 \mathrm{~m}^{2}\right)$. As āreas amostradas foram marcadas para que nao viessem ser novamente coletadas.

d) Preparo de amostras para anālise

Das amostras colhidas foram tomados seus pesos to tais, sem subdividir. em partes vegetativas. As amostras fo ram lavadas com água destiliada e desmineralizada, segundo recomendação de SARRUGE e HAAG (1974). Todas amostras foram secadas em estufa com circulação forçada de ar a $70-80^{\circ} \mathrm{C}$ e de pois pesadas para determinaça de matéria seca.

\section{e) Anālise quîmica dos nutrientes}

Para a determinação dos macro é micronutrientes utilizou-se dos seguintes métodos analiticos:

$N$ - método semimicro Kjehdahl; fósforo - colorimetria do metavanadato.

K - Fotometria de chama; Ca, Mg, B, Cu, Fe, Mn e Zn - Espectrofotometria de absorcão atômica, B - Colorimetria de curcumina; S - Espectrofotometria diferencial de absorção atômica - métodos estes citados em SARRUGE e HAAG (1974). 
f) Digestibilidade

o teste de digestibilidade"in vitro" da matéria se ca foi desenvolvido no Laboratório de Bromatologia do Departá mento de Zootecnia da Escola Superior de Agricultura "Luiz de Queiroz". A avaliação da digestibilidade in vitro da matéria seca foi efetuada sobre vinte e quatro amostras com duas repe tições. O método utilizado foi o de Tilley e Terry (1963) modificado por TINIMITT (1974).

h) Anālise Estatistica

Utilizou-se o delineamento inteiramente casualizado com 6 tratamentos e 4 repeticões. 


\section{RESULTADOS E DISCUSSÃO}

\subsection{Crescimento}

Os dados referentes ao acúmulo de M.S. de Panicum maximum cv. Makueni nas diferentes idades de amostragem encontram-se na tabela 2 .

os resultados obtidos permitem verificar que a produção de M.S. foi diferente entre os 30 dias e 180 dias somente.

A figura 1 , com a equação de regressão e seu respectivo coeficiente de determinação, apresenta a variação na produção de M.S., em gramas, em função da idade. Verifica-se um rāpido crescimento até aos 6 dias, uma vez que a primeira amostragem foi feita apōs 30 dias do rebaixamento da ārea do experimento.

Como foi mencionado anteriormente, foi forneci do uma adubação suplementar de nitrogênio. Atendendo às recomendações de CORSI (1975), que afirma que a adubação nitrogenada possibilita crescimento mais rápido e maior produção de 
Tabela 2. Peso da matéria seca $\left(\mathrm{g} / \mathrm{m}^{2}\right)$ da planta inteira de Pa nicum maximum, em função da idade. Média de quatro repetições :

\begin{tabular}{crr} 
Dias após & \multicolumn{3}{c}{ M.S. } \\
o rebaixamento & $\mathrm{kg} / \mathrm{ha}$ \\
\hline 30 & $76,85 \mathrm{a}$ & 768,50 \\
60 & $132,50 \mathrm{ab}$ & 1325,00 \\
90 & $125,75 \mathrm{ab}$ & 1257,50 \\
120 & $142,50 \mathrm{ab}$ & 1425,00 \\
150 & $105,00 \mathrm{ab}$ & 1050,00 \\
180 & $112,50 \mathrm{~b}$ & 1125,00 \\
\hline C.V. $(\%)$ & 23,22 & \\
d.m.S. (5\%) & 4,30 & \\
\hline
\end{tabular}

M.S., o que permite maior frequencia de cortes e um material de maior digestibilidade. No entanto, a figura 1, mostra que a produção máxima calculada para a planta deu-se aos 112 dias com 135,2 g/m², abaixo do valor máximo observado aos 120 dias com $142,5 \mathrm{~g} / \mathrm{m}^{2}$.

0 período de maior velocidade de acūmulo de M.S. estã entre os 30 a 60 dias e tambëm entre os 120 a 150 dias, quando hā um acentuado acréscimo, concordando com o encontrado por VIEIRA (1979) quando trabalhou com colonião que fịcou estabelecido um período dè 
30 a 75 dias, aumento este segundo o autor, se deveu quase que exclusivamente ao aumento de M.S. das folhas. A idade de amos tragem apresenta efeito significativo sobre o teor de M.S. do capim. A anālise de regressão do efeito da idade sobre o teor de M.S. do Makueni evidencia uma funcão quadrática, conforme se verifica na figura 1, cujo ponto de máximo ocorre aos 112 dias com $135,19 \mathrm{~g} / \mathrm{m}^{2}$ devido ao grande número de perfilhos que comecaram a se desenvolver.

Os resultados apresentados, concordam em parte com a tendência observada nos capins colonião, napier, gordura e pangola, de ocorrer aumento na producão de M.S. da planta com a idade, conforme resultados publicados por BOSE(1971); HAAG et alii (1967); WERNER e HAAG (1972); OKADA (1976); PEDREIRA e SILVEIRA (1972); MONTEIRO e WERNER (1977). Essa concordāncia parcial é explicada quando se verifica na figura 1 uma queda brusca na producão de M.S. aos 112 dias (calculado) e aos 120 dias (observado), deixando de concordar que com a maturação, a produção de M.S. cresce. Este decréscimo, envolve vários fatores. 0 primeiro destes fatorés é a frequência de corte que segundo MIDDLETON (1982), averiguando por um período de dois anos a producão de M.S. e a concentração de nitrogēnio em cinco gramineas forrageiras, inclusive o Makueni, que a queda na produção de M.S. e uma elevada concentração de nitrogènio se devem à frequência de corte, pois à medida que a frequência de corte aumentava, a produção diminuia. Tal fato não é comum em "gramīneas conforme Schofield (1944, 1945 citado por MIDDLETON;-1982). 


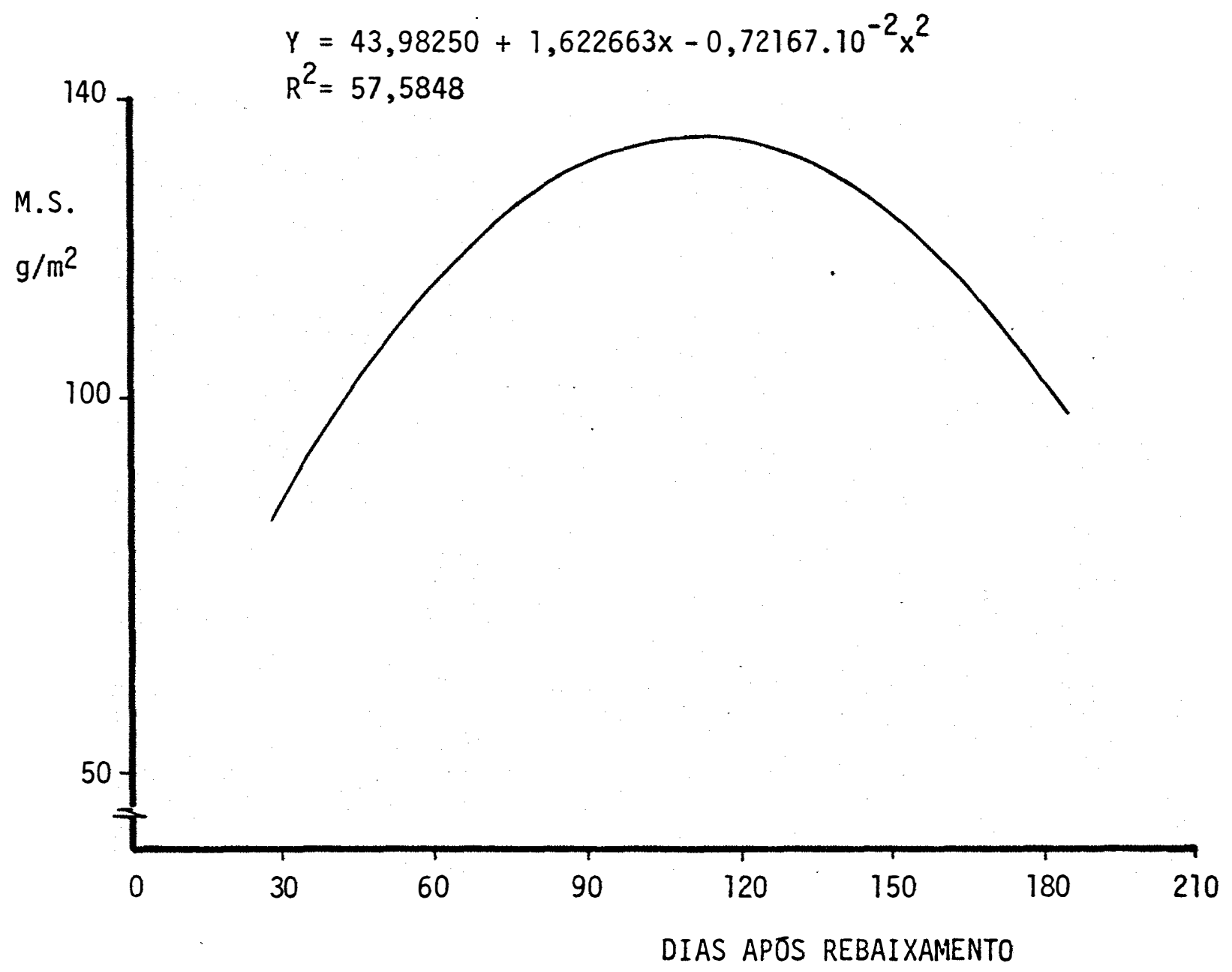

Figura 1 - Curva e equação de regressão da produção da matériá: seca (\%) da planta inteira de panicum maximum Jacq. cv. Makueni, em função da idade $(x)$. 
Mas o autor cita que Watkins e Lewy van Severen (1951) verificaram efeito semelinante. O segundo fator observado por Deimum et alii (1981) citados por CORSI (1984), as folhas recēm-expandidas ou em expansão contribuem para manter na planta forrageira elevada produtivida de de M.S.,uma vez que essas folhas são as mais eficientes em fotossintese. Quando expandidas completamente, as ligulas se encontram expostas, e a eficiēncia fotossintética delas diminui à medida em que senescem. Outro fator que influi na queda de produção de M.S. é o micro-ambiente. No crescimento das pastagens, observa-se que, após um crescimento lento, seguese um periodo no qual o crescimento é linear com o tempo,epos teriormente ocorre um declinio, quando as folhas superiores das pastagens impedem que as inferiores recebam luz suficiente para fotossintetizar eficientemente. Essa forma de crescimento sugeriria que as pastagens deveriam ser cortadas ou pasto readas, assim que a taxa de crescimento começasse a diminuir (ESCUDER, 1980).

4.2. Digestibilidade in vitro da matéria seca (DIVMS)

Os resultados obtidos permitem verificar a variação no coeficiente de digestibilidade diferindo em função da idade, conforme se observa na tabela 3 .

De modo geral, o maior DIVMS calculado ocorreu 
aos 30 dias com $51,94 \%$ abaixo do valor māximo observado, com $53,06 \%$, como mostra a figura 2 e a tabela 3 , com a equacão de regressão e seu respectivo coeficiente, segundo função li-' near. Observa-se tambēm na tabela 3 , que entre os 60 e 90 dias não houve diferenca significativa provavelmente pela pou ca idade. Pelo exame da figura 2 , observa-se que o DIVMS dimi nuiu com o aumento da idade da planta. DA SILVA e GOMIDE (1967) observaram este fenōmeno previamente em gramineas tropicais (sempre-verde, pangola e gordura) com cortes aos $2,4,6$ e 8 meses de idade, e verificaram um decréscimo na digestibilidade para o sempre-verde de $57,9 \%$ para $31,3 \%$. GOMIDE et alii (1979); BUTHERWORTH (1962); OLUBAJO (1974); REID et alii(1973); LOURENÇO et alii (1980); MINSON (1971b). VIEIRA (1979) também verificaram com colonião o decréscimo da digestibilidade com a idade.

Tabela 3. Digestibilidade in vitro da matéria seca da planta inteira de Panicum maximum Jacq. cv. Makueni, em função da idade.

\begin{tabular}{|c|c|c|c|c|c|c|}
\hline & 30 & Di & $\begin{array}{c}\text { a pōs } \\
90 \\
-1-(1\end{array}$ & cebaix & $\begin{array}{l}\text { nto } \\
150 \\
0\end{array}$ & 180 \\
\hline & $53,06 a$ & $45,04 b$ & $44,27 b$ & $42,27 b$ & $41,40 \mathrm{~b}$ & $29,42 c$ \\
\hline $\begin{array}{l}\text { C.V. }(\%) \\
\text { d.m.s. }(5 \%)\end{array}$ & $\begin{array}{l}3,34 \\
4,50\end{array}$ & & & & & \\
\hline
\end{tabular}




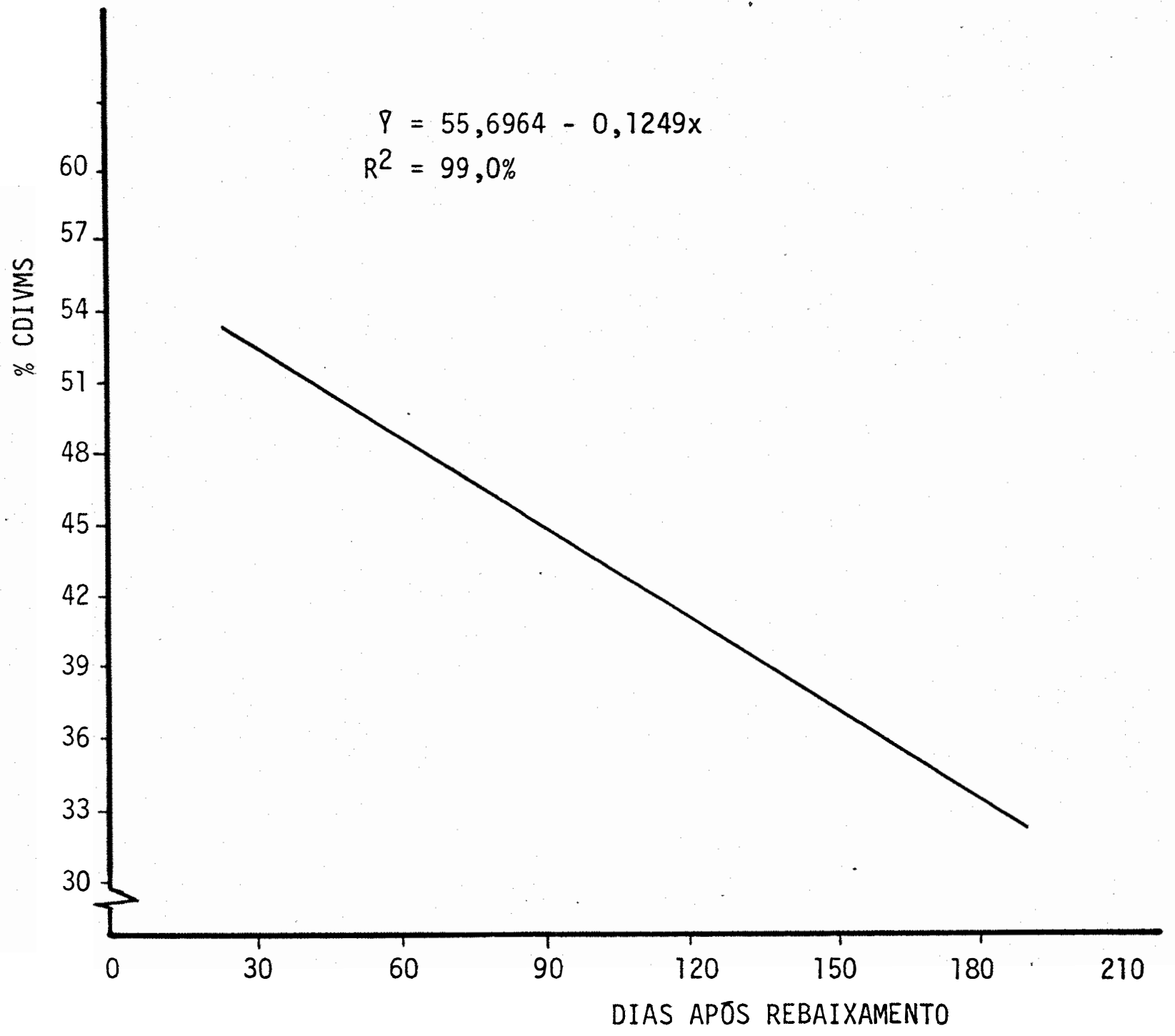

Figura 2 - Curva, equação de regressão e coeficiente de deter minação $\left(R^{2}\right)$, da digestibilidade "in vitro" da matéria seca (DIVMS) da planta inteira (Y), de Panicum maximum Jacq. cv. Makueni, em função da idade. 
Confrontando os coeficientes de digestibilidade obtidos por REID et alii (1973) em Uganda, para o Makueni nas idades de 4,8 e 12 semanas $(60,5 \% ; 49,6 \% ; 49,8 \%$, respectivamente) com os obtidos no presente trabalho para as mesmas idades $(53,06 \% ; 45,04 \%$ e $44,27 \%)$, observa-se uma pequena variação. Teores percentuais equivalentes( 10 corte $-53,5 \% ; 20$ corte $-58,1 \%$ e 30 corte $45,3 \%$ ) foram observados por MENESES et alii (1973) quando estudaram a digestibilidade aparente dos capins pangola, angola e colonião em trés estágios de desenvolvimento.

Para SILVEIRA (1970), o decréscimo no coeficien te de digestibilidade da M.S. é atribuído à queda do valor nutritivo da própria planta, com a maturação, alēm de alterações nos constituintes celulares. Para Raymond (1966) citado por SILVEIRA (1970), este fato ocorre porque as gramineas possuem maior quantidade de hemicelulose em relação à celulose, situação esta que se inverte com a maturidade, de sorte a provocar queda rāpida na digestibilidade. Em geral, é aceito que a lignificação das estruturas da parede celular retarda ou evita contato entre as enzimas digestivas e os constituintes da parede celular das forragens, o que concorre para diminuir a sua digestibilidade (VAN SOEST, 1975 e 1978).

Após uma revisão, VAN SOEST (1975 e 1978) estabeleceu que a maioria das espécies tropicais e temperadas. decresce nas suas qualidades nutritivas, à medidaem que o esta gio vegetativo progrediu com a maturidade. o decréscimo do 
valor nutritivo ocorre de maneira diferente para cada espécie, jā que esse fenômeno é regulado por um complexo de fatores. Assim a idade cronológica e a maturidade fisiológica pó dem ser identicas por serem fatores independentes. 0 efeito das baixas temperaturas e fotoperiodo curto provocariam retar damento no crescimento e alta qualidade da planta forrageira, devido a um atraso no processo de maturação, o que permite man ter por mais tempo a qualidade nutritiva da forragem.

Minson e Milford (1967), citados por GAVILANES et alii (1978), afirmam que os teores de proteina presentes na forragem podem afetar negativamente a digestibilidade daM.S. em gramineas tropicais, quando o nível estā abaixo de 7-8\%.Con frontando estas conclusões com a concentração de nitrogēnio em função da idade, observa-se que aos 30 e 60 dias, foram obtidos teores de proteina bruta $(N \% \times 6,25)$ acima do nível minimo $(7 \%)$, estando de acordo com os autores citados.

4.3. Concentração e acumulação de nutrientes

4.3.1. Macronutrientes

4.3.1.1. Nitrogēnio

A tabela 4 indica que as concentrações de nitrogēnio mc-s traram efeitos significativos sobre as diferentes: idades, enquanto que as quantidades acumuladas não diferiram entre as diferentes idades. 


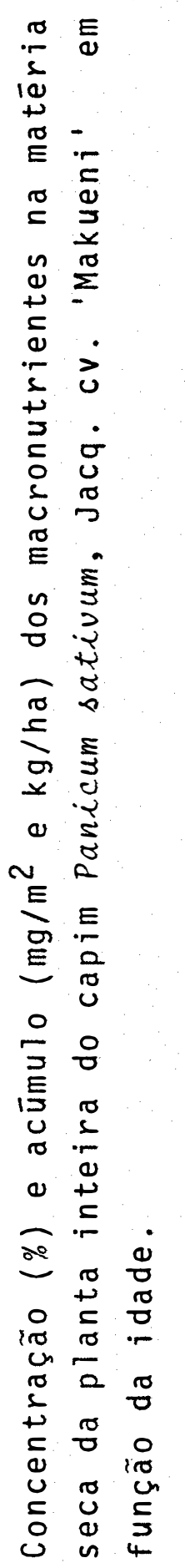

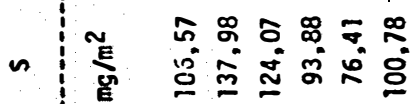

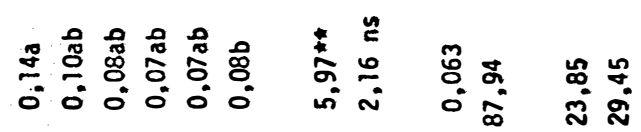

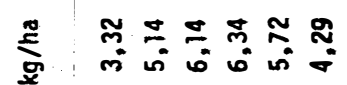

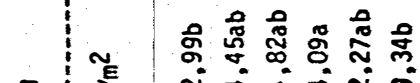

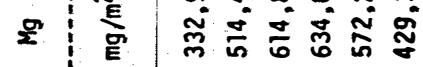

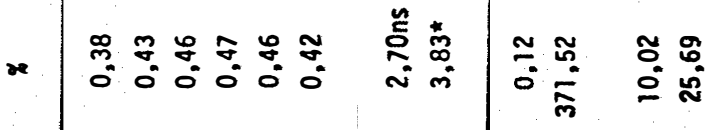

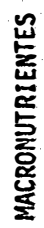

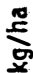

$\approx$

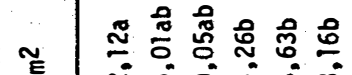

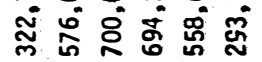

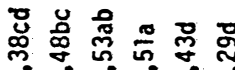

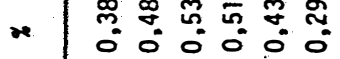

ฐ̊

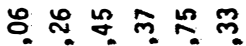

స - ర్లి స

ซึ

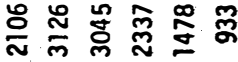

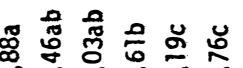

i i $=0$

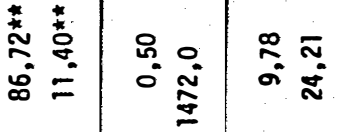

$\stackrel{0}{5}$

ำ ำ ำ

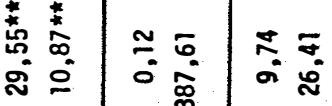

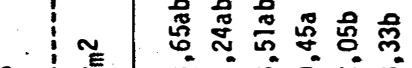

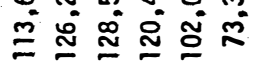

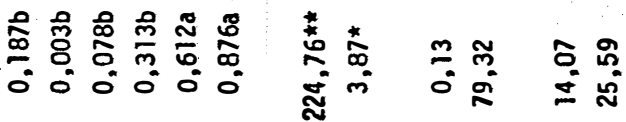

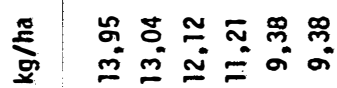

น

$=$ E

$\checkmark$

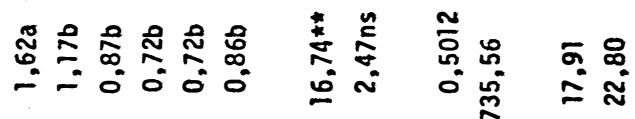

$\frac{\pi}{\infty}$

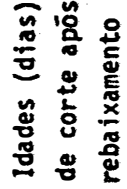

잉용요 용

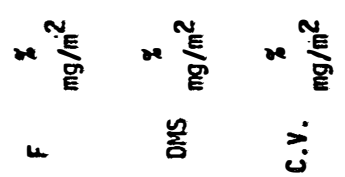


Observa-se na figura 3 que as concentrações de nitrogēnio diminuíram segundo uma equação de regressão qua drática, indicando um ponto de minimo aos 136 dias de idade, conl $0,70 \%$ de nitrogēnio, fato este verificado por GOMIDE et alii (1969) nos capins pangola, colonião, quicuio, napier e gordura.

A figura 3 evidencia qué a absorção de nitrogènio foi mais acentuada no início, pois a M.S. aumenta e esse aumento ocorre até aos 112 dias, fazendo com que a concentração de nitrogênio diminua devido a um efeito de diluição na planta. No período onde ocorre maior velocidade de acúmulo de M.S., en tre 30 a 60 dias, a concentração de nitrogēnio atinge seu pon to máximo, aos 30 dias com um teor de $1,62 \%$, conforme tabela 4. Segundo JARDIM et alii (1962a), a alimentação dos bovinos é considerada deficiente em proteina bruta, quando as pastagens apresentam um valor minimo de $7-8 \%(N \% \times 6,25)$ desse nutrien te na M.S. Observa-se que o teor satisfatório encontrado nes te estudo foi até aos 60 dias. Nas demais idades, os teores apresentaram-se abaixo do valor minimo estabelecido para a pro teina bruta.

HAAG et alii (1967) em estudo de absorção de macronutrientes por cinco espēcies de gramineas, verificaram que os teores de nitrogēnio decresceram com a idade e os capins colonião e gordura apresentaram concentrações de nitro- 


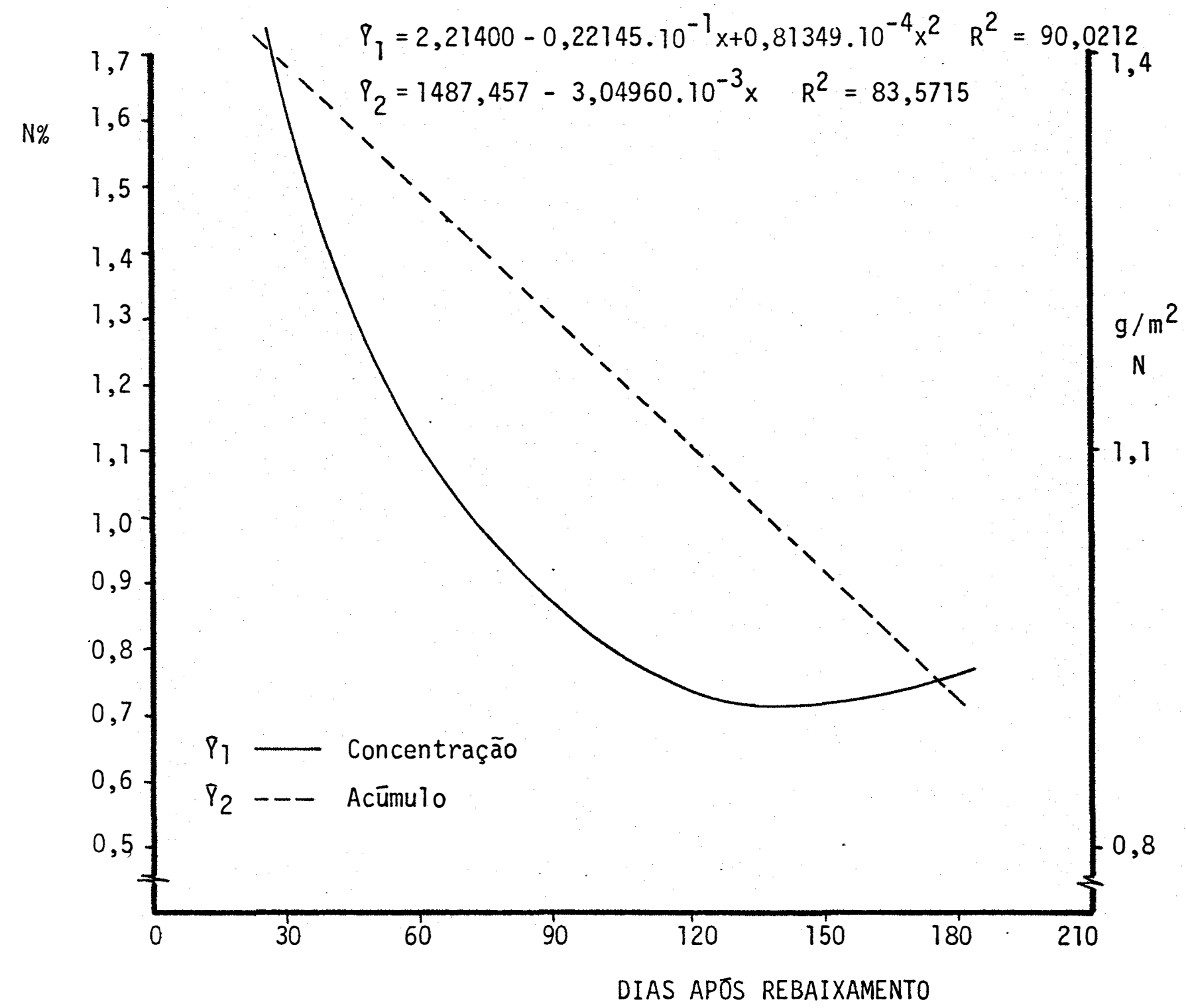

Figura 3 - Concentração e acūmulo de nitrogênio (Y) da planta inteira de Panicum maximum Jacq. Cv. Makueni, er função da idade $(x)$. 
gènio adequadas até aos 156 dias, atendendo ao mínimo de proteínas verificadas por JARDIM et alii (1962). O decréscimo desse nutriente com a idade também foi verificado por ASARE (1974) em Ghana, quando em estudo efetuado com Andropogon ga yanus encontrou como valores médios, para a planta inteira, de $1,76 \%$ e 1,23\%. ORELLANA e HAAG (1982) no Brasit encontraram pa ra a mesma espécie, valores médios nas folhas que variaram de $1 ., 36 \%$ a $1,20 \%$ até aos 140 dias, enquanto que no caule variaram de $0,79 \%$ aos 80 dias para $0,50 \%$ aos 140 dias, sendo portanto, consistentes os resultados obtidos no presente estudo.

\subsubsection{Fósforo}

As concentrações e o acūmulo de fósforo na M.S. acham-se expressas na tabela 4 e mostram efeitos significativos entre as diferentes idades.

Conforme se verifica na figura 4 , as concentra ções de fósforo mostram um decréscimo acentuado no inīcio do desenvolvimento com um ponto de inflexão àos 139 dias após o rebaixamento, atingindo uma máxima concentração de $0,876 \%$ de fós foro aos 180 dias, como mostra a tabela 4 . Aos 60 dias, a concentração de fósforo atinge a um mĩnimo com um teor de 0,003\%, acompanhando inversamente o acūmulo de M.S., cujo ponto de maior velocidade estā entre os 30 a 60 dias, ocorrendo um decréscimo na concentração de fósforo, mostrando um efeito de diluição. A partir dos 60 dias, verifica-se um crescimento rāpido, concordando em parte com GOMIDE (1976), 
HAAG et alii (1967), NASCIMENTO JUNIOR et alii (1976), PRÖSPE RO e PEIXOTO (1972) relatam que de modo geral, os teores de fósforo encontrados nos capins colonião, pangola, gordura, jaraguá e napier decrescem com a idade da planta para a haste, folha e planta inteira.

Segundo Iljin (1955) citado por HAAG et alii (1967),o limite de concentração de fósforo na forrageira é de $0,15 \%$ para bovinos adultos em regime de pastejo. E para Riggs (1958), citado por ANDREASI et alii $(1966,1967)$, o limite minimo de concentração de fósforo é da ordem de $0,11 \%$ a $0,13 \%$. O nível de fósforo encontrado por ACCIOLY (1972), em cem espēcies de gramineas nativas e exōticas na região de fortaleza, (CE) foi de $0,10 \%$ a $0,49 \%$, enquanto para o capim colonião a faixa encontrada por HAAG et alii (1967) foi de 0,24\% a 0,36\%. OYENUGA (1960) na Nigēria, encontrou uma variação na concentração de fósforo de $0,14 \%$ a $0,18 \%$ em colonião. A concentrá. ção de fósforo de $0,003 \%$ aos 60 dias é baixa, elevando-se até a $0,87 \%$ no final do ciclo aos 180 dias como se verifica na ta bela 4 .

As quantidades acumuladas de fósforo assinala das na figura 4, mostram que houve efeitos significativos com a idade. Os teores de acūmulo de fósforo no capim se traduzem por uma regressão quadrática. Os dados indicam que o acū mulo é máximo aos 90 dias, com $128,51 \mathrm{mg} / \mathrm{m}^{2}$, conforme mostra a tabela 4. Na figura 4, observa-se que a velocidade de acúmulo e acentuada entre os 30 a 60 dias, para depois crescer len- 


$$
\begin{array}{ll}
P_{1}=0,7275-0,0250 x+0,2518 \cdot 10^{3} x^{2}-0,6018 \cdot 10^{-6} x^{3} & R^{2}=85,57 \% \\
P_{2}=90,7250+0,9367 x-0,5739 \cdot 10^{-2} x^{2} & R^{2}=54,92 \%
\end{array}
$$

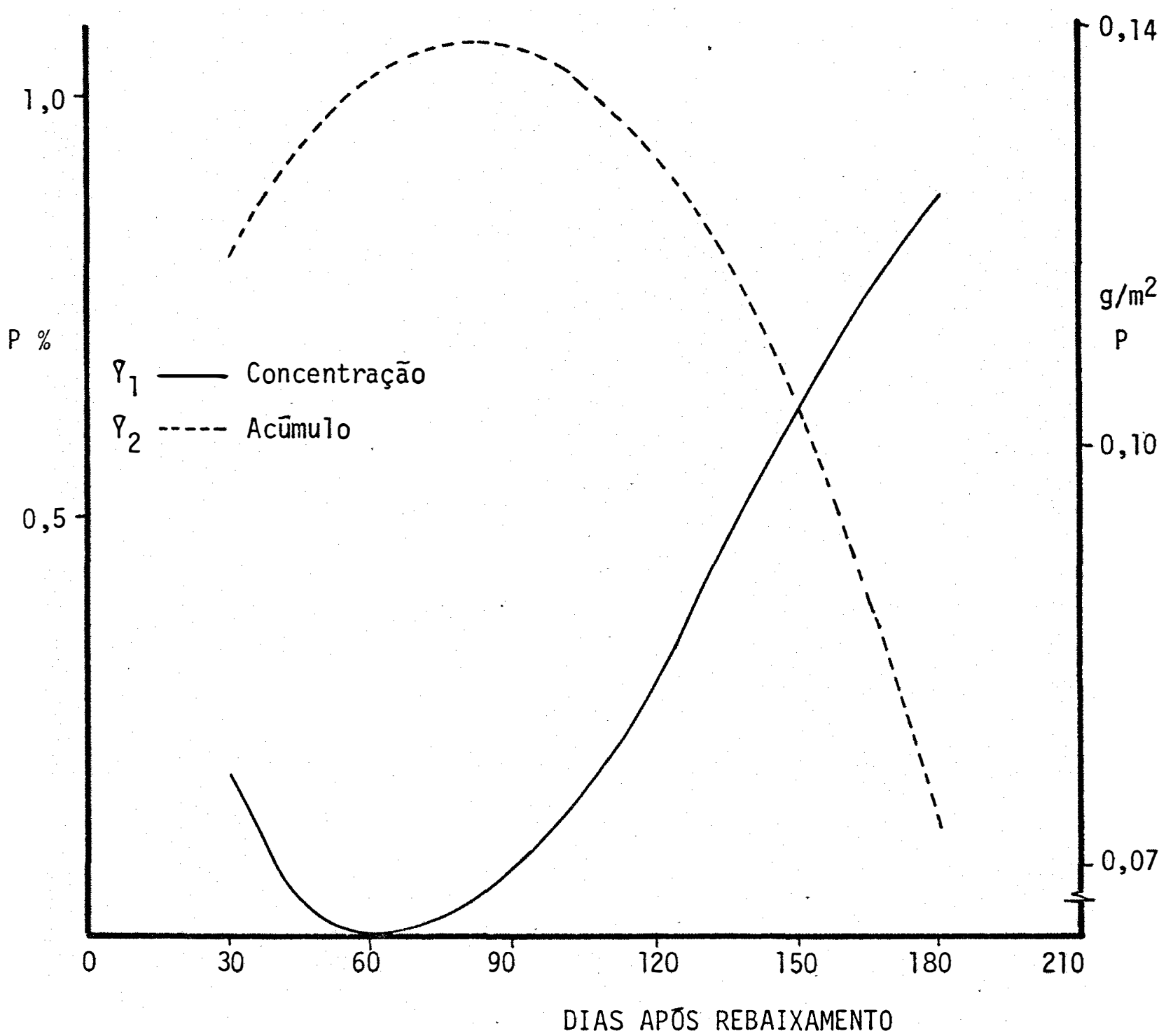

Figura 4 - Concentração e acúmulo de fósforo (Y) da planta in teira de Panicum maximum Jacq. cv. Makueni, em fun ção da idade $(x)$. 


$$
\begin{aligned}
& P_{1}=3,312373-0,014145 x \quad R^{2}=91,00 \% \\
& P_{2}=-488,3333+117,9771 x-0,2922 \cdot 10^{-2} x^{3} \quad R^{2}=94,5766
\end{aligned}
$$

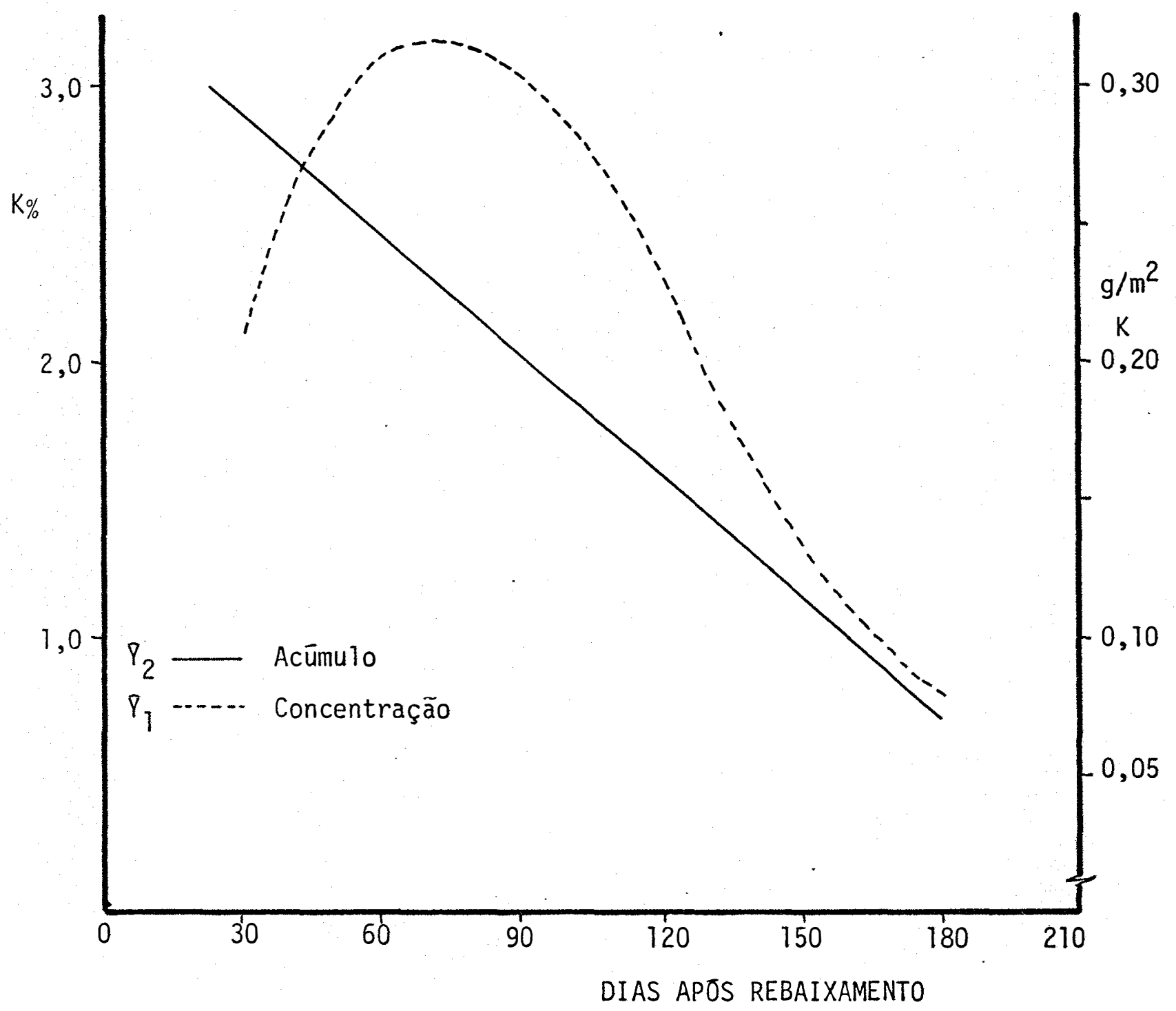

Figura 5 - Concentração e acūmulo de potāssio (Y) da planta inteira de Panicum maximum Jacq. cr. Makueni, em função da idade $(x)$. 
tamente até aos 90 dias, e com o avanço da idade, o acúmulo decresce rapidamente.

\subsubsection{Potássio}

As concentrações e o acūmulo na M.S. acham-se expresso na tabela 4 , e mostram efeitos significativos ( $P$ $>0,01)$ entre as diferentes idades.

As concentrações de potàssio, conforme ilustra a figura 5, diminuem gradualmente em função da idade, enquadran do-se em uma equação de regressão linear, variando de $2,88 \%$ a $0,76 \%$, como mostra a tabela 4 . Esta tendēncia linear não foi observada por VIEIRA (1979) em colonião. Observação semelhan te foi verificada por ORELLANA E HÄÂG (1982), em Andropogon gayanus, com uma faixa de variação para as folhas de 1,79\% a 1,27\% e para os caules variaram de $2,41 \%$ a $1,45 \%$ de potássio. HAAG et alii (1967) observaram uma faixa de variação de 3,89\% a 2,98\% com cortes de 28,56 e 84 dias para o colonião,embora o napier apresentasse elevada concentração do referido elemento.

PERDOMO et alii (1977), obtiveram para o capim Guinē o maior teor de K, em pocentagem de M.S., no corte aos 42 dias como po $\lambda$ de verificar com seguintes dados: 28 dias $(2,71 \%), 42$ dias $(2,86 \%)$ e 56 dias $(2,10 \%)$. Estes valores foram observados em anālise de planta inteira. Em comparação com os teores obtidos no presente trabalho, verifica-se que os dados encontrados estão um pouco abaixo aos dos referidos autores. 
Há sempre uma tendēncia de diminuição do teor de potássio com envelhecimento da planta, conforme observaram HAAG et alii (1967), WERNER e HAAG (1972) nos capins gordura, colonião, jaraguá e napier, ITALIANo et alii (1982b) no Amazonas, com capim colonião em degradação.

o teor mínimo de potássio na planta, para satisfazer às exigências de ruminantes é de $0,5 \%$, segundo WARD (1966). No presente estudo, não se observa teor inferior a $0,5 \%$ em quaisquer das idades. SANCHEz (1976) relata que concentrações de $1 \%$ de potāssio na M.S. podem ser consideradas ótimas. Confrontando o afirmado com os resultados obtidos no presente trabalho, verifica-se que o teor que se encontra abai xo desse limite é o registrado aos 180 dias. A diminuição nas concentrações de potássio encontra explicação em BLUE e TERGAS (1969), que atribuem as perdas do referido elemento nas for ragens devido a sua translocação deste elemento das folhas para as raizes e destas para o solo.

As quantidades acumuladas de potássio para a planta inteira mostraram efeitos significativos $(P>0,01)$ em função da idade, conforme mostra a tabela 4 . Observa-se que os teores decresceram com a idade, verificando a produção māxima calculada de $3199,76 \mathrm{mg} / \mathrm{m}^{2}$ aos 71 dias para decrescer a $933,19 \mathrm{mg} / \mathrm{m}^{2}$ aos 180 dias, acontecendo uma produção mỉnima estimada para os 187 dias com $902,83 \mathrm{mg} / \mathrm{m}^{2}$. 


\subsubsection{Cálcio}

As concentrações e o acūmulo de cālcio na M.S. acham-se expressos na tabela 4 e mostram diferenças significa tivas com a idade.

No entanto, essas diferenças nas concentrações de cálcio são evidentes aos 90 dias com $0,51 \%$ de cálcio e aos 180 dias com $0,29 \%$ de cálcio; nas demais idades essas diferenças não foram expressivas. Ao examinar a figura 6 , as con centrações são expressas em uma equação de segundo grau, veri ficando-se uri aumento gradual no início, até atingir um ponto de mäximo aos 90 dias com $0,53 \%$, conforme tabela 4. Deste estádio em diante, a concentração decresce inversamente ao acūmu10 da M.S., com evidente efeito de diluição, pois entre os 30 a 60 dias, 0 acúmulo de M.S. atinge sua maior velocidade, e aos 112 dias ocorre a máxima produção de M.S., de $131,1 \mathrm{~g} / \mathrm{m}^{2}$ deixando de coincidir com o maior acúmulo de cálcio, registra do aos 120 dias com $694,2 \mathrm{mg} / \mathrm{m}^{2}\left(0,69 \mathrm{~g} / \mathrm{m}^{2}\right)$, conforme mostra a tabela 4 .

Ao contrārio do verificado no presente estudo, VIEIRA (1979), com colonião obteve para as concentrações de cálcio um decréscimo linear com a idade.

A faixa de variação da concentração verificada no presente trabalho é de 0,53 a 0,29\% de cálcio, havendo um decréscimo no teor de elemento com a maturação da planta. 


$$
\begin{array}{ll}
P_{1}=0,213000+0,65726 \cdot 10^{-2} x-0,33928 \cdot 10^{-4} x^{2} & R^{2}=58,32 \\
P_{2}=-0,61600+1.4,95482 x-0,73132 \cdot 10^{-1} c^{2} & R^{2}=60,39
\end{array}
$$

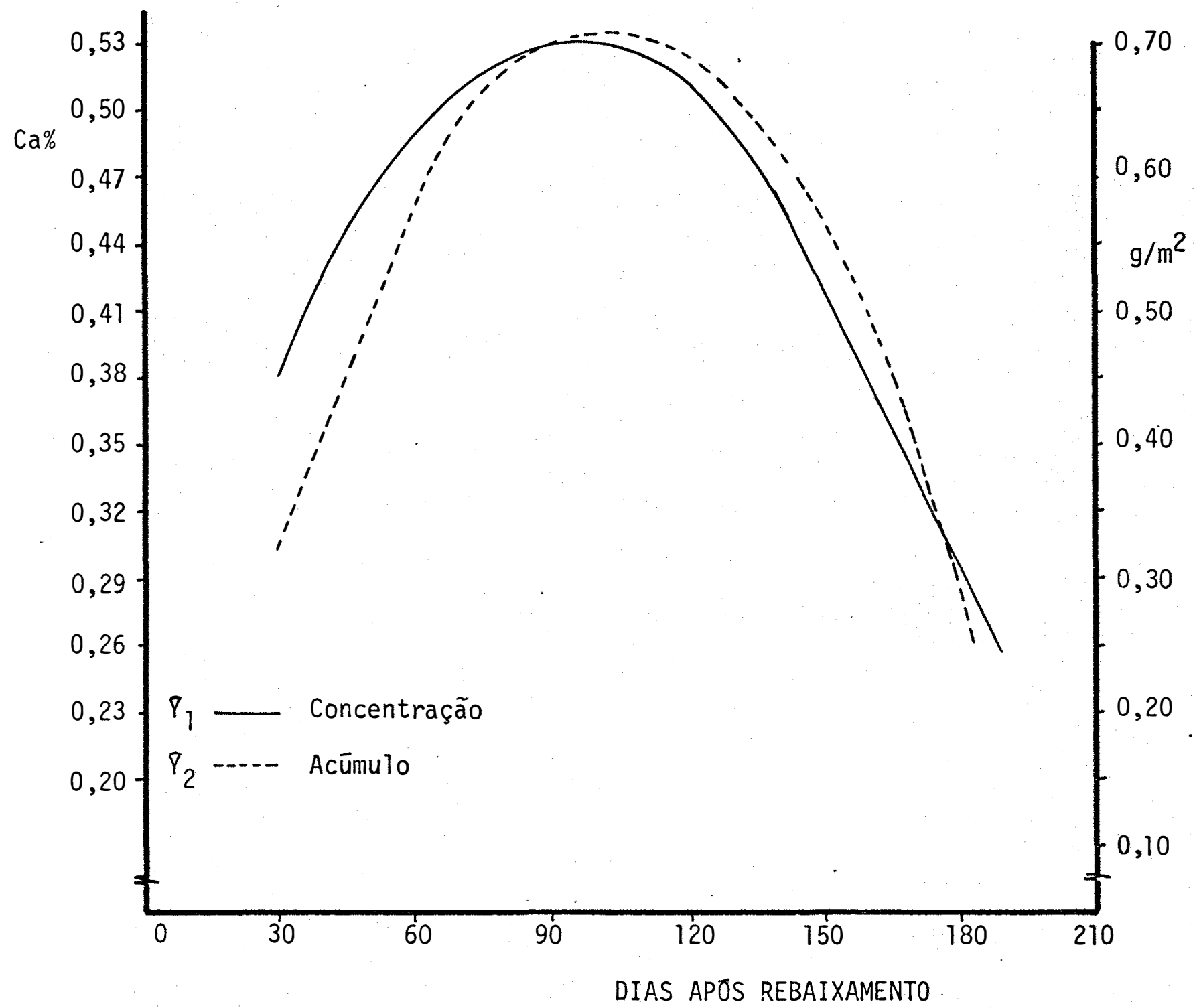

Figura 6 - Concentração e acūmulo de cālcio (Y) da planta inteira de Panicum maximum Jacq. cv. Makueni, em fun ção da idade $(x)$. 
Concordando com as observacões verificadas por ANDREASI et alii (1966, 1967), nos capins jaraguá e gordura, HAAG et alii (1967) com colonião, gordura, jaraguá e pangola, cujos valores médios foram $0,26 \%$ aos 28 dias, $0,29 \%$ aos 56 dias e $0,41 \%$ aos 84 dias, SOUSA et alii (1979) obtiveram valores médios de cál cio $0,34 \%$ e $0,67 \%$ em levantamento no norte do Estado de Mato Grosso, SILVA et alii (1982) encontraram concentrações médias de cálcio nas amostras forrageiras que variaram de 0,028\% a $0,43 \%$ para as estaçoes das chuvas e da seca, respectivamente, ITALIANO et alii (1981), em trēs cortes efetuados no capim ja raguá, verificaram que a concentração de cālcio diminuiu do primeiro para o segundo corte, aumentando no terceiro corte e obtiveram as respectivas concentrações médias de $0,45 \%, 0,44 \%$ e $0,52 \%$ de cálcio.

0 NRC (1980) recomenda $0,43 \%$ de cálcio, em relação à M.S. da dieta, para uma vaca leiteira com $500 \mathrm{~kg}$ e ca pacidade de produção de leite inferior a $11 \mathrm{~kg}$ diārios. Para novilhos de corte em crescimento, a recomendação do NRC (1976) é de 0,18 a 1,04\% de cálcio. De acordo com o nỉvel mínimo estabelecido pelo NRC (1980), verifica-se que os teores encontrados no periodo de 60-150 dias $(0,48-0,43 \%)$ no presente trabalho estão adequados. Quanto a faixa estabelecida. para novilhos de corte, observa-se que os teores obtidos para todas as idades, estão de acordo com o NRC (1976). 
Segundo BLUE e TERGAS (1969), que durante a es tacão seca a concentração de cálcio nas forragens não decresce e as perdas nutritivas são, provavelmente, devidas ao méto do de translocacão de nutrientes das folhas para as raizes e destas para o solo. Mas este fato, se verificou com os teores obtidos aos 120 dias $(0,51 \%), 150$ dias $(0,29 \%)$ época de seca no presente trabalho.

Quanto às quantidades acumuladas, conforme mos tra a tabela 4 , verifica-se uma diferença significativa aos 30 dias, com $322,12 \mathrm{mg} / \mathrm{m}^{2}$, e aos $120 \mathrm{dias}$, com $694,26 \mathrm{mg} / \mathrm{m}^{2}$. Como se observa na figura 6 , houve no inicio do desenvolvimen to um rápido acúmulo, segundo uma equação de regressão quadrá tica, verificando um ponto de máximo aos 90 dias com $700 \mathrm{mg} /$ $\mathrm{m}^{2}$, começando a diminuir rapidamente após 90 dias. Essa queda pode ser explicada pela natureza imóvel do cálcio quando este chega às folhas não se verificando sua redistribuição.

\subsubsection{Magnésio}

Como se verifica na tabela 4 , as concentracões de magnésio na M.S. não diferiram em função da idade, enquanto que as quantidades acumuladas do elemento mostraram efeitos significativos com a idade $(P>0,05)$.

Ao decompor a Soma dos Quadrados da concentra: ção do magnēsio em função da idade, a anālise de regressãomos tra efeito significativo segundo uma equaça quadrática, indi 
cando uma variação definida da concentração de magnésio com o tempo, como se verifica na figura 7. Ao examinar a figura 7 e a tabela 4, verifica-se um crescimento gradativo, atingindo $0,47 \%$ de magnésio aos 120 dias, decrescendo em seguida.

MARTINEZ et alii (1984) em revisão sobre os ma cronutrientes em gramineas, tabularam as concentracões dos nu trientes contida na M.S. de diversos capins em diferentes ida des, e verificaram que de um modo geral a concentracão de ma nésio na maior parte dos casos não variou significativamente com a idade, seguindo uma equação quadrática, com um aumento seguido por posterior decréscimo, como se verifica no trabaTho de NASCIMENTO JUNIOR et alii (1976), ou tende a crescer conforme o observado por PROSPERO e PEIXOTO (1972).

ADAMS (1975) relata que a variacão de magnésio nas forrageiras na estação seca foi de $0,07 \%$ a $0,75 \%$ com coeficiente de variação de $33 \%$. HAAG et alii (1967) em pangola, gordura, jaraguá e colonião citam como deficiente. do pon to de vista de nutricão animal, a forrageira que apresenta va lor menor que $0,1 \%$ de magnésio na M.S. Confrontando os teores obtidos no presente trabalho com os niveis minimos determinados pelos autores, verifica-se que os valores são compatíveis com os teores já encontrados. Com relação às quantidades acumuladas de magnésio, conforme mostra a tabela 4 , verifica-se uma diferença significativa aos 39 dias com $332,9 \mathrm{mg} / \mathrm{m}^{2}$ e aos 120 dias com $634,09 \mathrm{mg} / \mathrm{m}^{2}$. A figura 7 mostra que a curva de a cúmulo de magnésio cresce de modo rápido, atingindo a um pon- 


$$
\begin{array}{ll}
P_{1}=0,30800+0,29535 \cdot 10^{-2} x-0,12896 \cdot 10^{-4} x^{2} & R^{2}=75,57 \\
P_{2}=70,42499+10,10383 x-0,4505 \cdot 10^{-1} x^{2} & R^{2}=72,71
\end{array}
$$

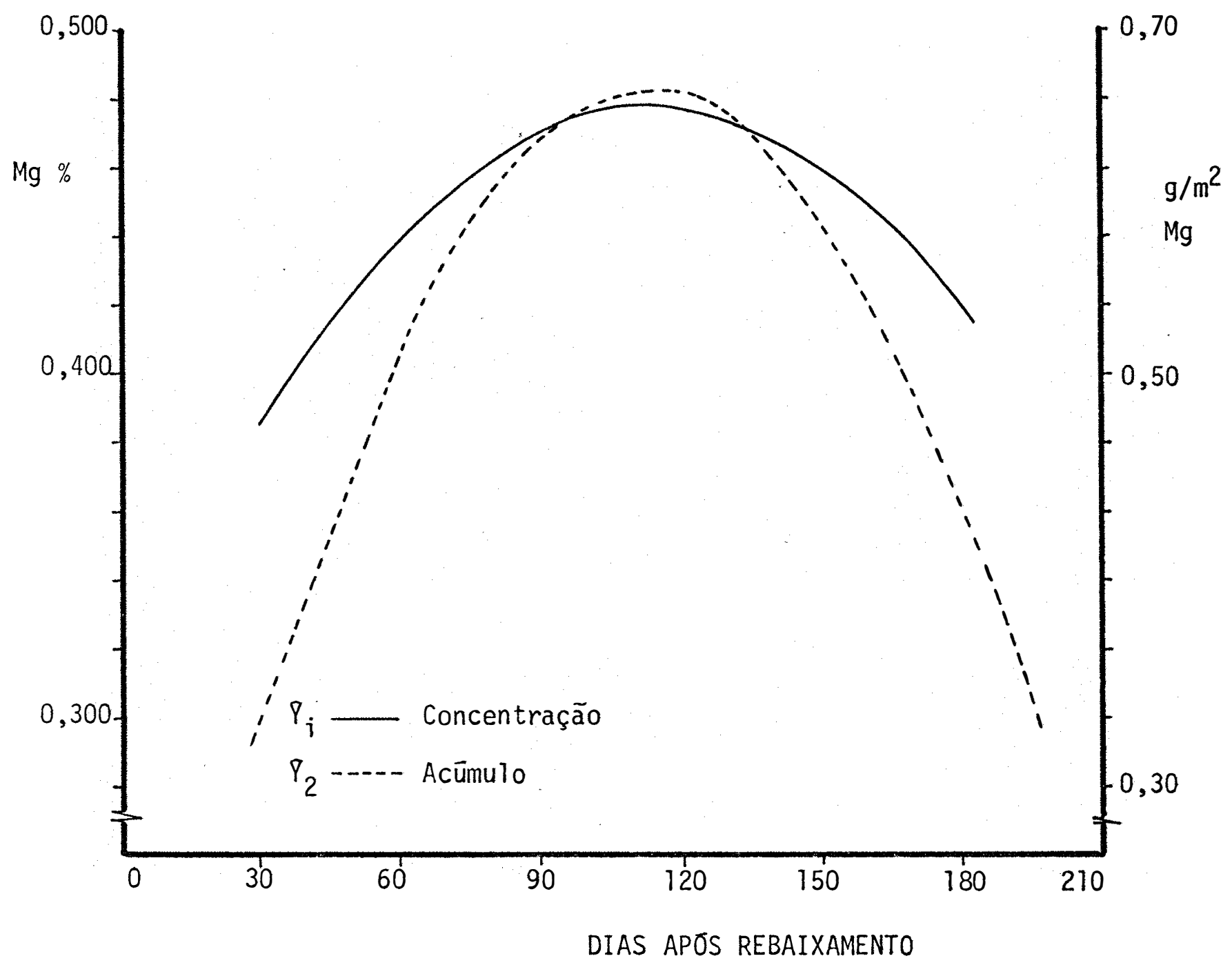

Figura 7 - Concentração e acūmulo de magnēsio (Y) da pianta inteira de Panicum maximum Jacq. cr. Makueni, em função da idade $(x)$. 
to de máximo, com uma produção calculada de $636,89 \mathrm{mg} / \mathrm{m}^{2}$. aos 112 dias, producão esta maior que a observada aos 120 dias com $634,09 \mathrm{mg} / \mathrm{m}^{2}$. Verifica-se também que a partir dos 30 dias, o acūmulo de magnésio no Makueni aumenta linearmente, indicando que a partir deste perīodo o magnésio acumulou rapidamente na planta.

\subsubsection{Enxofre}

As concentracões de enxofre no capim Makueni mostraram diferenças significativas $(P>0,01)$ com a idade, enquanto que as quantidades acumuladas do elemento não, como mostra a tabela 4. As concentrações de enxofre na M.S. como se verifica na tabela 4 , de um modo geral, diferiram significativamente em função da idade. Entretanto, essas diferenças são expressiva aos 30 dias, com $0,14 \%$ de enxofre,eaos 180 dias, com $0,08 \%$ de enxofre. Nas demais idades essas diferencas mostraram pequenas variacões. Ao examinar a figura 8 , as concentracões decrescem com o envelhecimento da. planta, segundo uma equação de regressão quadrática. Observa-se que um ponto de minimo foi atingido aos 120 dias, com $0,07 \%$, crescendo posteriormente. Este fenōmeno foi verificado por HAAG et alii (1967) quando trabalharam com os capins colonião, gordura, jaraguá, na pier e pangola cultivados em solucão nutritiva, aos 84 dias. os autores observaram que o enxofre foi o elemento menos extraido, variando entre $0,63 \mathrm{~g} / \mathrm{kg}$ de M.S. e $0,18 \mathrm{~g} / \mathrm{kg}$ de M.S. 


$$
\begin{array}{ll}
P_{1}=0,18400-0,163035 \cdot 10^{-2} x+0,60515 \cdot 10^{-5} x^{2} & R^{2}=81,26 \\
P_{2}=0,8333+5,0862 x-0,574250 x^{2}+0,179181.10^{-3} x^{3} & R^{2}=56,8725
\end{array}
$$

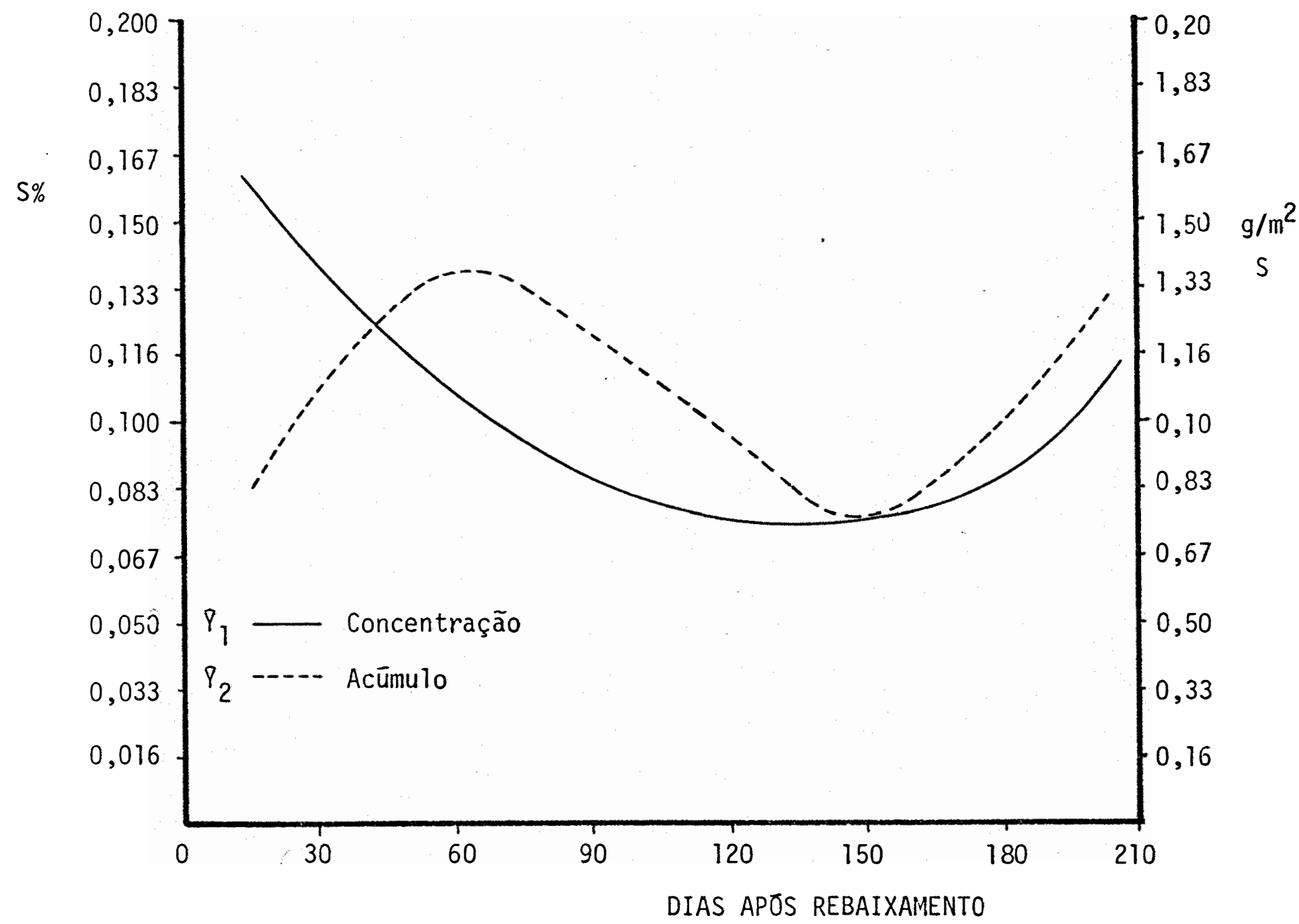

Figura 8 - Concentração e acūmulo de enxofre (Y) da planta in teira de Panicum maximum Jacq. Ev. Makueni, em fun ção da idade. 
produzida, o que representa 0,49 a $3,65 \mathrm{~g}$ de enxofre por vaso. PROSPERO e PEIXOTO (1972) verificaram no capim elefante teores bastante variáveis com a idade, contrariando o observadó no presente trabalho.

CIAT (1978) estabeleceu um nível minimo de $0,1 \%$ de enxofre para as gramineas. Dentro do estabelecido verifica - se que até aos 90 dias os teores encontram-se inferiores ao minimo, sen que a utilização deste capim só é adequada para enxofre até aos 60 dias.

\title{
4.3.2. Micronutrientes
}

\author{
4.3.2.1. Cobre
}

As concentrações e o acúmulo de cobre na M.S. acham-se expressas na tabela 5 e mostram efeitos significati$\operatorname{vos}(P>0,01)$ entre as diferentes idades.

As diferenças nas concentrações de cobre são. evidentes aos 30 dias, com 7,69 ppm, e aos 150 dias, com 3,71 ppm; nas demais idades verifica-se que estas diferenças são pouco expressivas conforme mostra a tabela 5 . Na figura 9, as concentracões são exp̣ressas por uma equação linear. Verifican do um decréscimo nas concentrações com a maturação da planta. As concentrações variaram de 7,69 ppm aos 30 dias a 2,72 ippm aos 180 dias. 0 drecréscimo da concentração de cobre, em função da idade, foi também observado por GOMIDE et alii (1969) em colonião, napier, jaraguá, pangola e quicuio e 

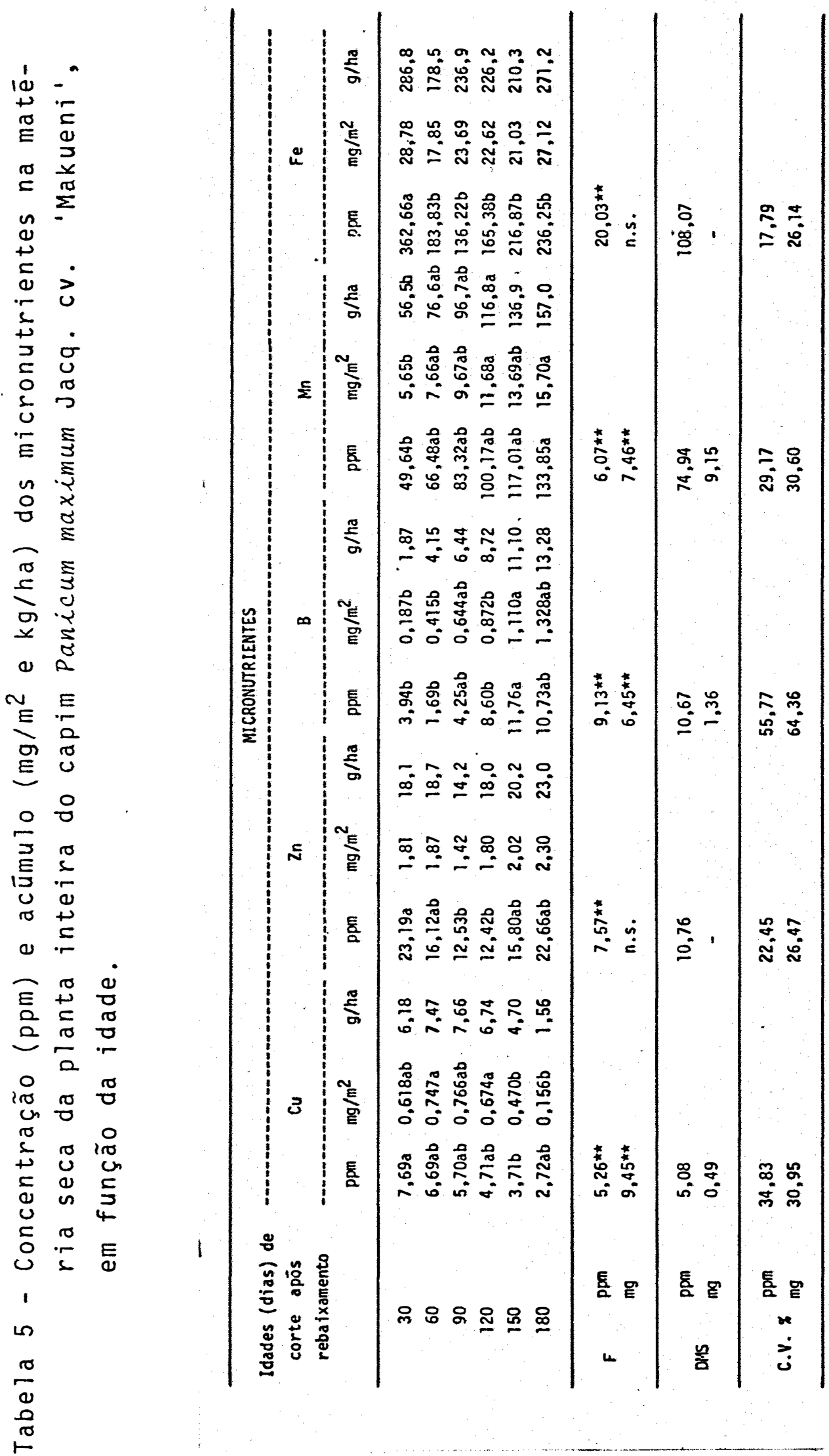
por PERDOMO et alii (1977). FERNANDES e SANTIAGO (1972) em amostras de forrageiras no Estado de Mato Grosso e TEIXEIRA et alii (1971) no Brasil Central, encontraram niveis de cobre va riando de 2,50 a $3,03 \mathrm{ppm}$, demostrando deficiência desse mine ral. SILVA et alii (1982) encontraram teor médio de 0,75 ppm desse nutriente no capim colonião, na estacão das chuvas, e na estação seca o teor foi de 0,62 ppm.

GALLO et alii (1974) encontraram em $48 \%$ das di versas forrageiras amostradas no Estado de São Paulo um teor de 4-8 ppm de cobre, considerado como normal, e $20 \%$ acina de 10 ppm considerado acima do normal. De acordo com o NRC (1976), Hational Research Council, a. recomendacão de cobre para os bovinos ē de 4 ppm. GAVILLON e QUADROS (1976) relataram que o nīvel de cobre para gado bovino é de 4 ppm, quando o nível de molibdēnio é baixo (de 1 a 5 ppm). Davis (1958), citado por TEIXEIRA et alii (1971), informam que o teor de cobre nas pas tagens da flórida pode variar de 1 a 2 ppm a niveis superiores a $25 \mathrm{ppm}$.

Harvey (1952), citado por TEIXEIRA et alii (1971), afirmou que a deficiência de cobre em ruminantes está associada com niveis de cobre nas pastagens de 2,5 a 5,0 ppm na M.S.. Dos limites em relação aos limites constantes no NRC (1976) verifica-se que teores de cobre obtidos no presente tra balho atende às necessidades do animal até aos 90 dias. Entre tanto, dos limites estabelecidos por Harvey (1952), citado por TEIXEIRA et alii (1971), verifica-se que todas as idades a- 
mostradas acham-se adequadamente supridas neste micronutriente.

Os resultados das quantidades acumuladas en contram-se na tabela 5 , e mostram diferencas significativas, sendo expressas por uma equacão de segundo grau, conforme mos tra a figura 9. Estas diferencas nas quantidades acumuladas são expressivas aos 60 dias, com $0,747 \mathrm{mg} / \mathrm{m}^{2}$, e aos $150 \mathrm{dias}$, com $0,470 \mathrm{mg} / \mathrm{m}^{2}$. No entanto, nas demais idades essas diferencas são pequenas como podem ser verificadas na tabela 5 . Na figura 9 , observa-se que o acūmulo de cobre aumenta rapidamen te atingindo um ponto de máximo, calculado aos 80 dias com $0,77 \mathrm{mg} / \mathrm{m}^{2}$, um pouco acima do valor máximo observado aos 90 dias, com $0,76 \mathrm{mg} / \mathrm{m}^{2}$, com um posterior decréscimo acentuado com o desenvolvimento da planta.

\subsubsection{Zinco}

As concentracões de zinco na M.S. mostram efe tos significativos $(P>0,01)$ entre as diferentes idades, enquanto que as quantidades acumuladas não diferiram significativamente em função da idade como mostra a tabela 5.

As diferenças nas concentrações de zinco são evidentes aos 30 dias, com 23,19 ppm, e aos 90 dias, com 12;53 ppm; estas diferenças expressivas não se verificam nas demais idades. Observando a figura 10, verifica-se que as concentracões acham-se expressas por uma equacão de regressão quadrāti 


$$
\begin{aligned}
& P_{1}=8,68333-0,33095 \cdot 10^{-1} x \quad R^{2}=79,5812 \\
& P_{2}=0,37775+0,98654 \cdot 10^{-2} x-0,61636 \cdot 10^{-4} x^{2} \quad R^{2}=71,1971
\end{aligned}
$$

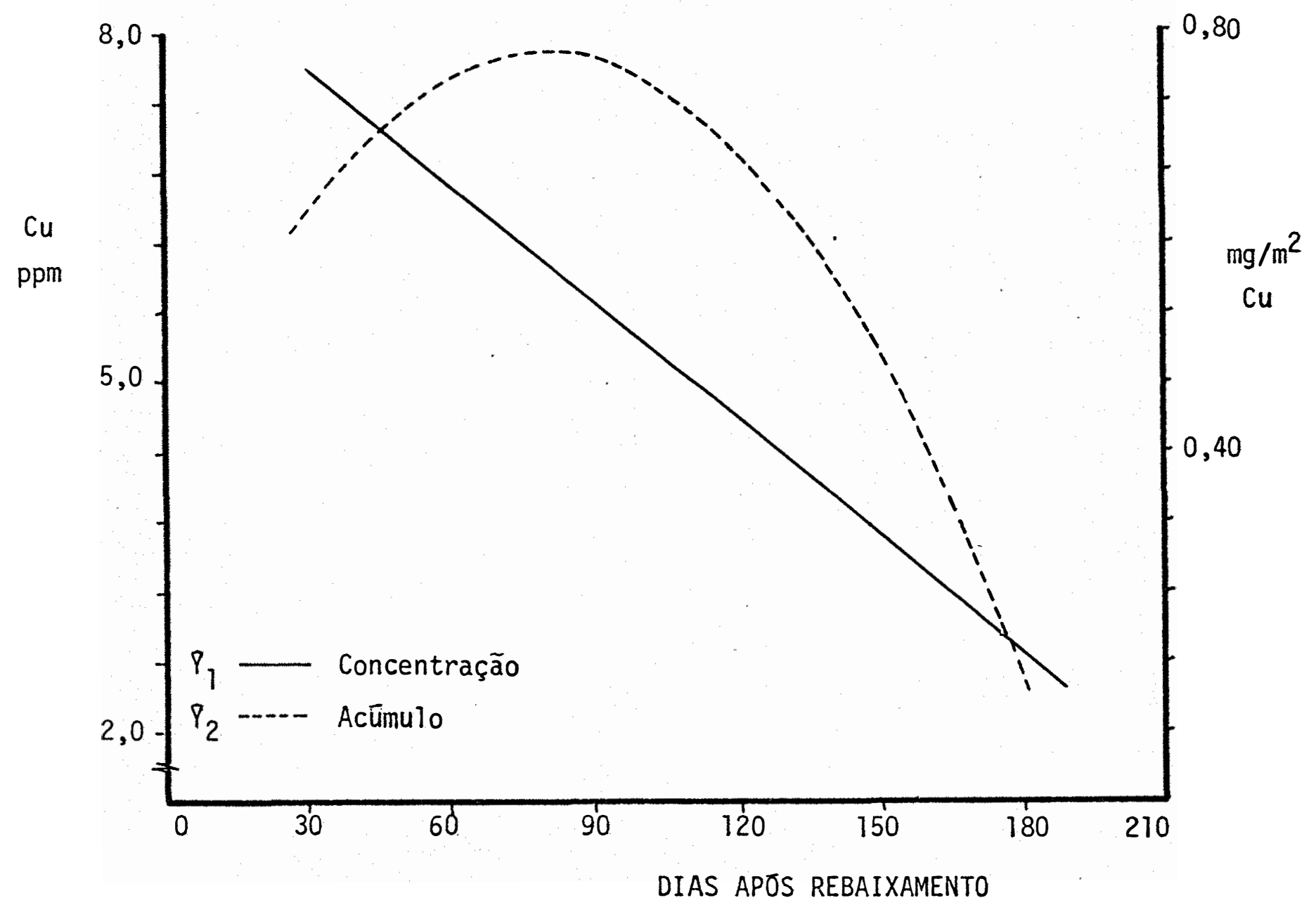

Figura 9 - Concentração e acūmulo de cobre (Y) da planta inteira de Panicum maximum Jacq. cv. Makueni, em função da idade $(x)$. 
ca, diminuindo no inicio, atingindo um ponto de minimo calculado aos 106 dias com 12,0 ppm um pouco abaixo do valor minnimo observado, que ocorreu aos 120 dias com 12,42 ppm. Após atingir este ponto minimo, as concentrações elevam-se de modo gradual.

Os niveis usuais de zinco nas plantas variam, segundo CHAPMAN (1966) e GLADSTONE e LONERAGAN (1967), de 10 a $100 \mathrm{ppm}$, sendo mais altos nas plantas jovens e decrescendo com a idade. Para ADAMS (1975), os niveis de zinco nas forrageiras variam de 8 a 300 ppm.

Nas 178 amostras forrageiras do Ceará, analisa das por ACCIOLY (1972), os nīveis de zinco encontrados nas gramineas foram de 6 a $68 \mathrm{ppm}$. Diferenças significativas nos teores de zinco em gramineas e leguminosas não foram encontra dos por GALLO et alii (1974); os niveis desse nutriente eram inferiores às necessidades dos animais. SILVA et alii (1982) encontraram teores médios de zinco nas pastagens de colonião, pangola e angola que variaram de 2,88 a 3,27 ppm na época das chuvas é de 2,40 a 2,83 ppm na seca. E para o colonião o teor médio de zinco nas chuvas foi de 3,27 ppm e na seca 2,83 ppm. UNDERWOOD (1968) nos Estados Unidos da América do Norte encon trou teores médios que variaram de 19 a 62 ppm de zinco nas gramineas de pastagens de clima temperado.

GLADSTONE e LONERAGAN (1967) afirmam que em decorrência do variável estạdo de nutrição da planta grandes 
oscilacões são observadas no que concerne aos nīveis de inge tão dos elementos por parte dos animais mantidos em condicões de pastejo. Segundo esses autores, a concentração de zinco no caule e folhas das espécies, declinou com a idade embora com diferentes graus de intensidade. Mas ANDREASI et alii verificaram que com a maturação da planta, os conteūdos de zinco para os capins colonião, jaraguá e gordura foram significativamente mais elevados em relaça aos registrados nas plantas mais novas.

Confrontando os dados dos autores citados com os obtidos no presente trabalho, verifica-se que até atingir o ponto minnimo houve concordāncia com GLADSTONE e LONERAGAN (1967) após este estágio, os resultados passaram a concordar com as observações feitas por ANDREASI et alii. (1969). Não constitui, potanto, regra geral, que os teores de zinco diminuem com o envelhecimento da planta.

Com relação aos niveis determinados por CHAPMAN (1966) e GLADSTONES e LONERAGAN (1967), verifica-se que os teores de zinco obtidos no presente estudo estão dentrodes sas especificações.

Segundo O NRC (1970), o limite minimo de norma lidade de zinco nas forrageiras é de $10 \mathrm{ppm}$, e com vista às exigências dos animais o NRC (1980) recomenda que o nível de zinco para novilhos é de 30 a 40 ppm na M.S.. Para vacas leiteiras com $500 \mathrm{~kg}$ e produção de leite inferior a $11 \mathrm{~kg}$ diārios, O NRC (1978) recomenda 40 ppm de zinco na M.S. da dieta. 


$$
\begin{aligned}
& P_{i}=33,75000-4,09821 x+0,0019 x^{2} \quad R^{2}=97,5359 \\
& P_{2}=\text { Dados observados }
\end{aligned}
$$

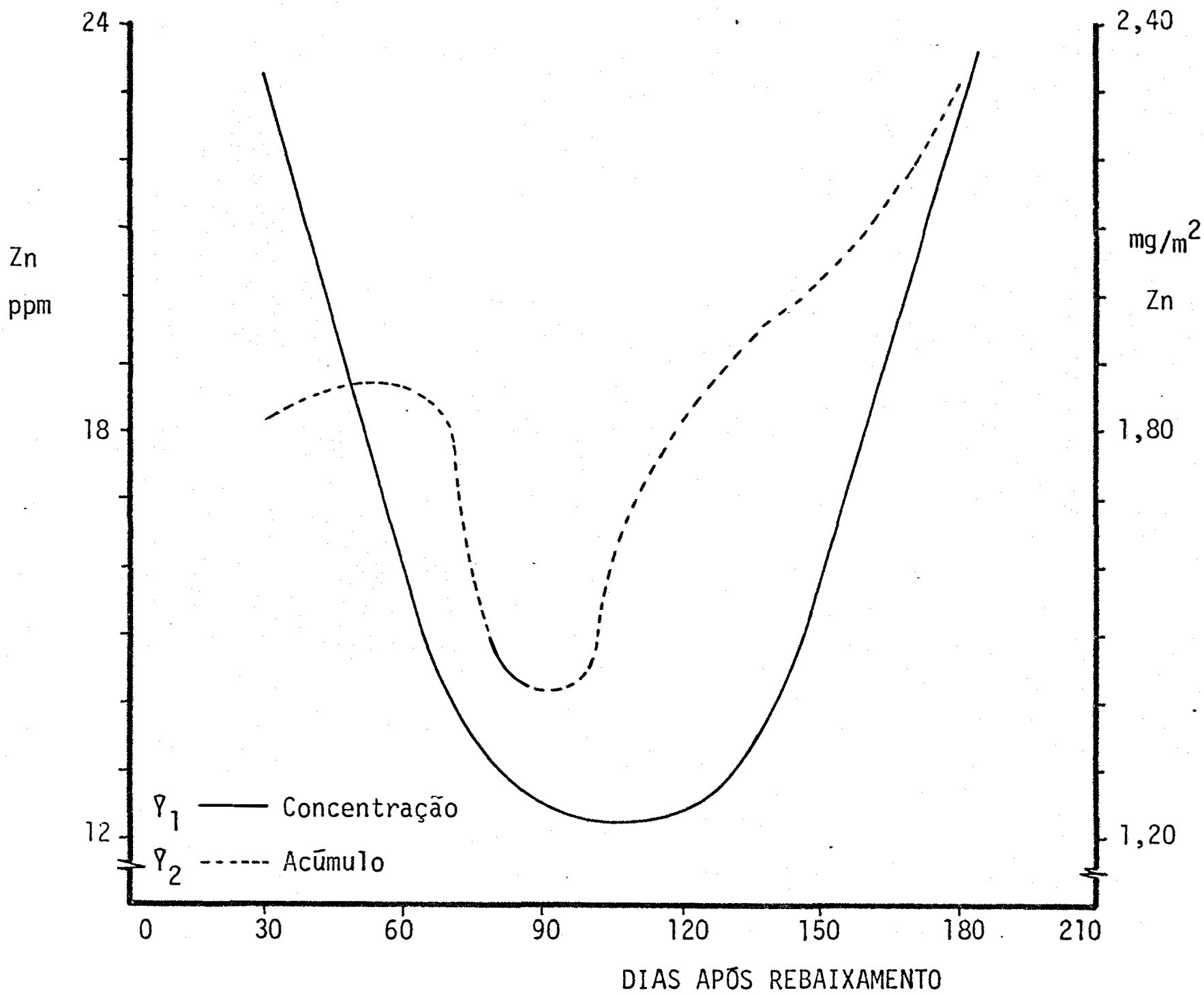

Figura 10 - Concentração e acūmulo de zinco (Y) da planta inteira de Panicum maximum Jacq. cr. Makueni, em. função da idade $(x)$. 
Com vista às exigências dos bovinos, observa-se que os teores obtidos no presente trabalho estão compatíveis com as especificacões estabelecidas pelo NRC (1970), deixando de atenderas recomendações do NRC (1976) na sua totalidade, enquanto que para as vacas leiteiras os resultados não atendem às suas exí gências.

Com relação às quantidades acumuladas de zinco, estas não diferiram significativamente em função da idade, in dicando um comportamento semelhante da' planta inteira em cada idade.

\section{$4 \cdot 3 \cdot 2 \cdot 3$. Boro}

As concentracões e o acúmulo de boro na M.S. acham-se expressos na tabela 5 e mostram efeitos significati $\operatorname{vos}(P>0,01)$ entre as diferentes idades.

As diferencas nas concentracões de boro são evidentes aos 30 dias, com 3,94 ppm, e aos 150 dias, com 11,76 ppm; conforme se observa na tabela 5. Ao examinar a figura 11, as concentracões são expressas por uma equacão cūbica, verifi cando-se um decréscimo acentuado, atingindo um ponto de mīnimo aos 60 dias com 1,69 ppm, crescendo posteriormente sendo verificada uma variação de $4,25 \mathrm{ppm}$ aos 90 dias, $8,60 \mathrm{ppm}$ aos 120 dias e $11,76 \mathrm{ppm}$ aos 150 dias. Sendo registrado um ponto máximo observado aos 150 dias $(11,76 \mathrm{ppm})$ teor abaixo do māxi mo calculado aos 160 dias com 12,0 ppm, decrescendo gradual- 


$$
\begin{aligned}
& P_{1}=14,0-0,498511 x+0,600 \cdot 10^{-2} x^{2}-0,1851 \cdot 10^{-4} x^{3} \quad R^{2}=50,1523 \\
& P_{2}=-0,4059 \cdot 10^{-1}+0,7607.10^{-2} x \quad R^{2}=47,4522
\end{aligned}
$$

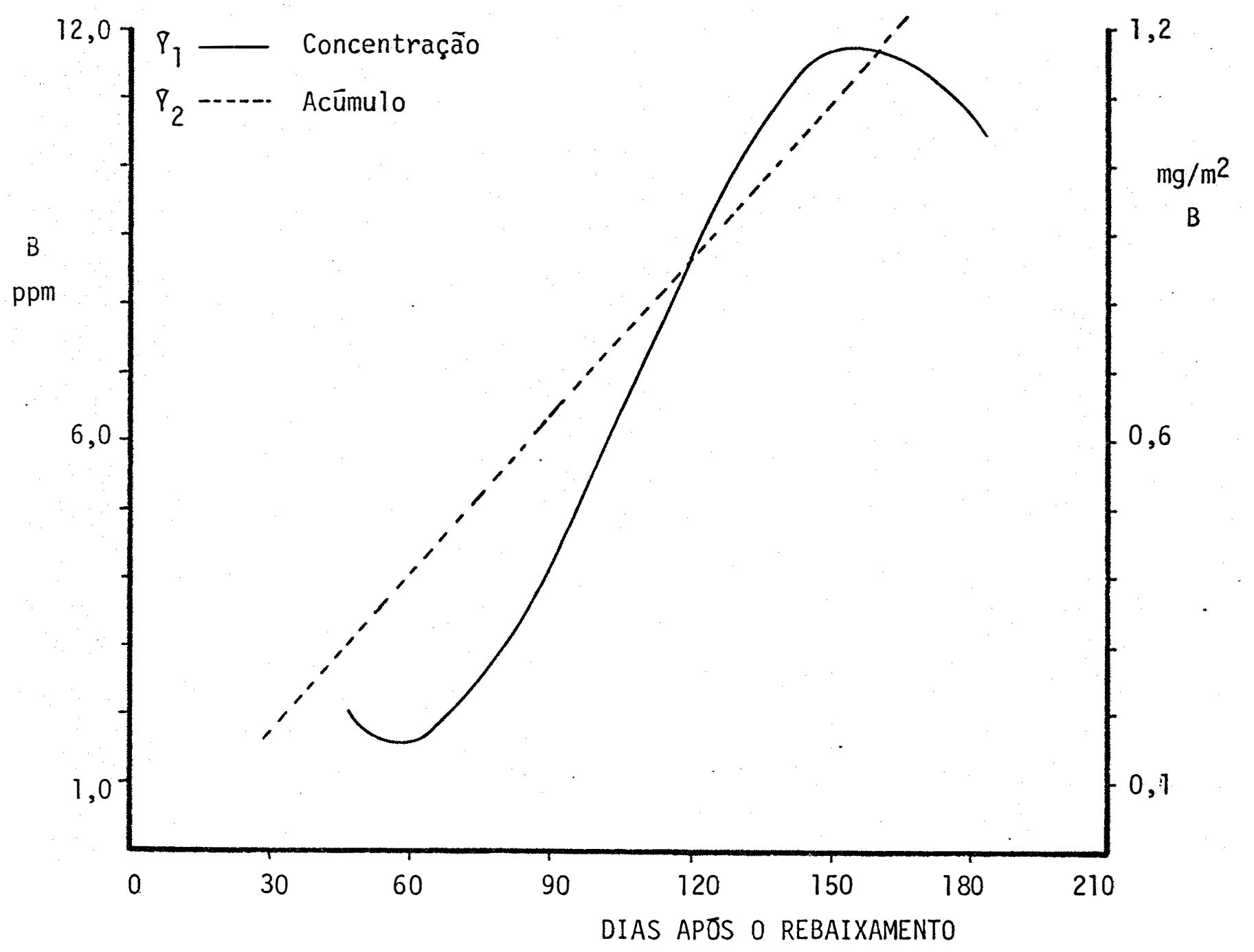

Figura 11 - Concentração e acūmulo de boro (Y) da planta inteira de Panicum maximum Jacq. cr. Makueni em fun. ção da idade $(x)$. 
mente.

Com relacão às quantidades acumuladas na M.S., estas mostraram efeitos significativos, conforme tabela 5 , ve rificando-se que estas diferencas ocorreram aos 120 dias com $0,87 \mathrm{mg} / \mathrm{m}^{2}$ e aos 150 dias com $1,11 \mathrm{mg} / \mathrm{m}^{2}$. Ao examinar a figura 11 e a tabela 5, observa-se que as quantidades acumuladas de boro, aumentam com a maturação da planta, levando a entender que a parte aērea toda, tem sua maior velocidade de acūmu 10 iniciada aos 60 dias.

GALLO et alii (1974) verificaram que a maior freauencia dos teores de boro ocorreu na faixa de 10-50 ppm em $82 \%$ das amostras forrageiras analisadas no Estado de São Paulo. As gramineas com uma frequência de $80 \%$ das amostras e tudadas contiveram 10-20 ppm de boro.

Segundo CHAPMAN e PRATT (1961) o teor de boro na M.S. das plantas usualmente é de 10-100 ppm, podendo variar abaixo de 5 a acima de 1.500 ppm. Esse elemento também se acha presente nos tecidos animais, porém, não hā evidēncia de sua essencialidade (UNDERWOOD, 1962).

\subsubsection{Manganēs}

As concentrações e o acúmulo de manganês

M.S. mostram efeitos significativos $(P>0,01)$ entre as dife rentes idades como assinala a tabela 5 .

As concentracões de manganês diferiram signifí 
cativamente como pode verificar na tabela 5 , aos 30 dias, com $49,64 \mathrm{ppm}$, e aos 180 dias, com $133,85 \mathrm{ppm}$, enquanto que nas demais idades estas diferenças não foram significativas. Ao examinar a figura 12 , as concentracões de manganés enquadram- se em uma equação de regressão linear, mostrando um crescimento com a maturidade da planta, com uma variaça média de $16,84 \mathrm{ppm}$ entre as idades.

0 decréscimo no teor de manganēs com a idade foi verificada por VIEIRA (1979) em colonião. GOMIDE et alii (1969), trabalhando com sempre-verde no Brasil Central, verificaram que com $200 \mathrm{~kg} / \mathrm{ha}$ de $\mathrm{nitrogen}$ io houve aumento no teor de manganés com o envelhecimento da planta, cujos teores, em ppm de M.S., passaram de 172 ppm na 4 ạ semana para 312 ppm na 36 ạ semana. Este fenômeno não foi verificado pelos autores em napier e pangola que tiveram comportamento não definido. GOMI DE et alii (1969) constataram que a adubacão de nitrogênio in . fluiu sobre a concentração de manganēs, aumentando-a.

$$
\text { ACCIOLy (1972), em anālises feitas em } 178 \text { amos }
$$

tras gramineas do Cearā, observou uma variaça nos teores de manganēs de 3 a 96 ppm. Beeson (1945) citado por. UNDERWOOD (1968), encontrou teores de manganēs que variaram de 96 a 815 ppm.

Confrontando esses teores de manganês com os encontrados no presente estudo verifica-se que os mesmos estão abaixo dos encontrados por Beeson (1945) citado po UNDER 
WOOD (1968), e em relação aos encontrados por ACCIOLY (1972) os teores encontrados no presente trabalho se encaixam nos ni veis estabelecidos.

SOUSA et alii (1981) fizeram um levantamento das deficiencias minerais no norte do Estado de Mato Grosso,e obtiveram elevadas concentracões de manganēs nas forrageiras na estaça da seca, quando as plantas estavam mais velhas. Este fato mostra que o manganès possui baixa translocacão nos tecidos das forrageiras, aumentando sua concentracão com a idade das plantas. Os mesmos autores observaram elevadas concentrações de manganēs para o capim sempre-verde e leguminosas, com teores médios de 420 a 250 ppm respectivamente. Com concentrações intermediārias ( 191 e 174 ppm ) de manganés, seguiram-se as forrageiras nativas e o capim colonião. Das observacões feitas por estes autores, pode-se concluir que os resultados obtidos no presente trabalho são concordantes. Observa-se também que os teores mé dios de manganès obtidos, para os capins sempre-verde, de 420 ppm, e para o colonião, de 174 ppm, estão acima do teor médio observado para a cultivar em estudo, com 117,0 ppm.

Segundo Davis (1955), citado por ANDREASI et alii (1968), teores de 10 ppm de manganēs atendem às exigências de crescimento normal dos bovinos, e niveis oscilando en tre 20 e 70 ppm devem figurar nos alimentos ou racões dos an $\underline{i}$ mais em reproducão. Davis (1955), citado por ANDREASI et alii 


$$
\begin{array}{ll}
P_{1}=32,80000+0,56142 x & R^{2}=91,2265 \\
P_{2}=3,63851+0,67050 \cdot 10^{-1} x & R^{2}=71,0254
\end{array}
$$

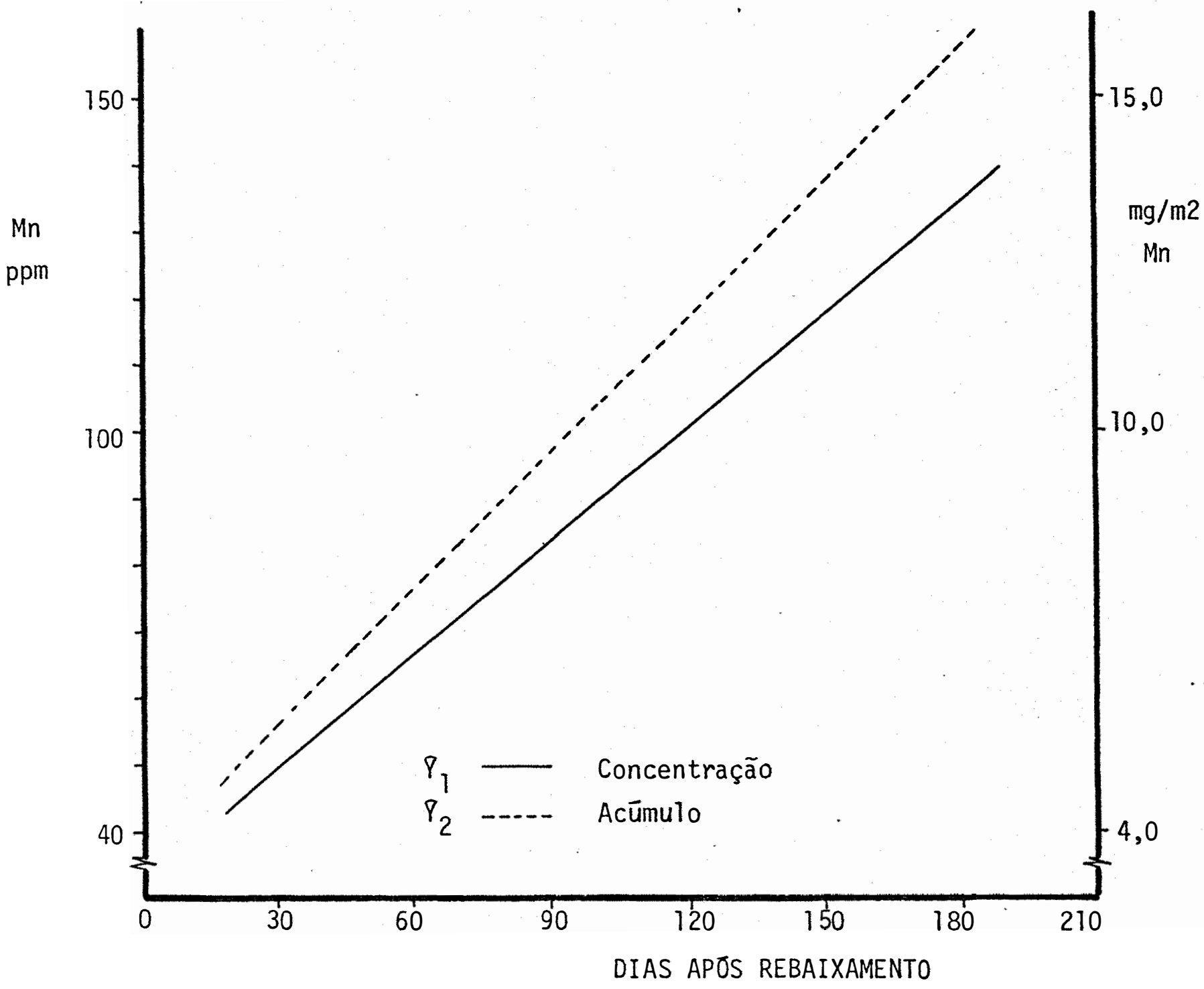

Figura 12 - Concentração e acúmulo de manganēs ( $Y$ ) da planta inteira de Panicum maximum Jacq. cv. Makueni, em função da idade $(x)$. 
(1968) registra ainda que, para bovinos e ovinos, o limite mä ximo da faixa de normalidade estaria ao redor de 150 ppm. Underwood (1957), citado por ANDREASI et alii (1968), registrou em pastagens teores que oscilaram entre 44 e 114 ppm de manga nês, enquanto que DE ALBA e DAVIS (1957), em pastos da Costa Rica, obtiveram 60,5 a 332,2 ppm; VICENTE-CHANDLER e EIGAREL LA (1962) verificaram 161 a 190 ppm de manganēs no napier e, GAVILLON (1963) encontrou māximo de 450 ppm em pastagens nat vas do Rio Grande do Sul. Verifica-se que os resultados encon trados no presente trabalho estão dentro dos limites estabele cidos por Underwood (1957) e de Davis (1955), citados po ANDREASI et alii (1968), e abaixo dos limites encontrados pelos demais autores.

Quanto às quantidades acumuladas de manganês, verifica-se que estas apresentaram diferenças significativas, conforme mostra a tabela 5 , aos $30 \mathrm{dias,} \mathrm{com} 5,65 \mathrm{mg} / \mathrm{m}^{2}$, e aos 180 dias, com $15,70 \mathrm{mg} / \mathrm{m}^{2}$. A figura 12 mostra efeitos $1 \mathrm{i}$ neares das quantidades acumuladas em função da idade, verificando-se um crescimento gradual com a maturação da planta.

\subsubsection{Ferro}

As concentrações de ferro em função das diferentes idades apresentaram diferencas significativas $(P>0,01)$, enquanto que as quantidades acumuladas não mostraram efeitos significativos com idade, como pode-se observar na tabela 5. 
$P_{1}=727,166-15,8492 x+0,13339 x^{2}-0,1360.10^{-3} x^{3} \quad R^{2}=85,35$

$P_{2}=$ Dados observados

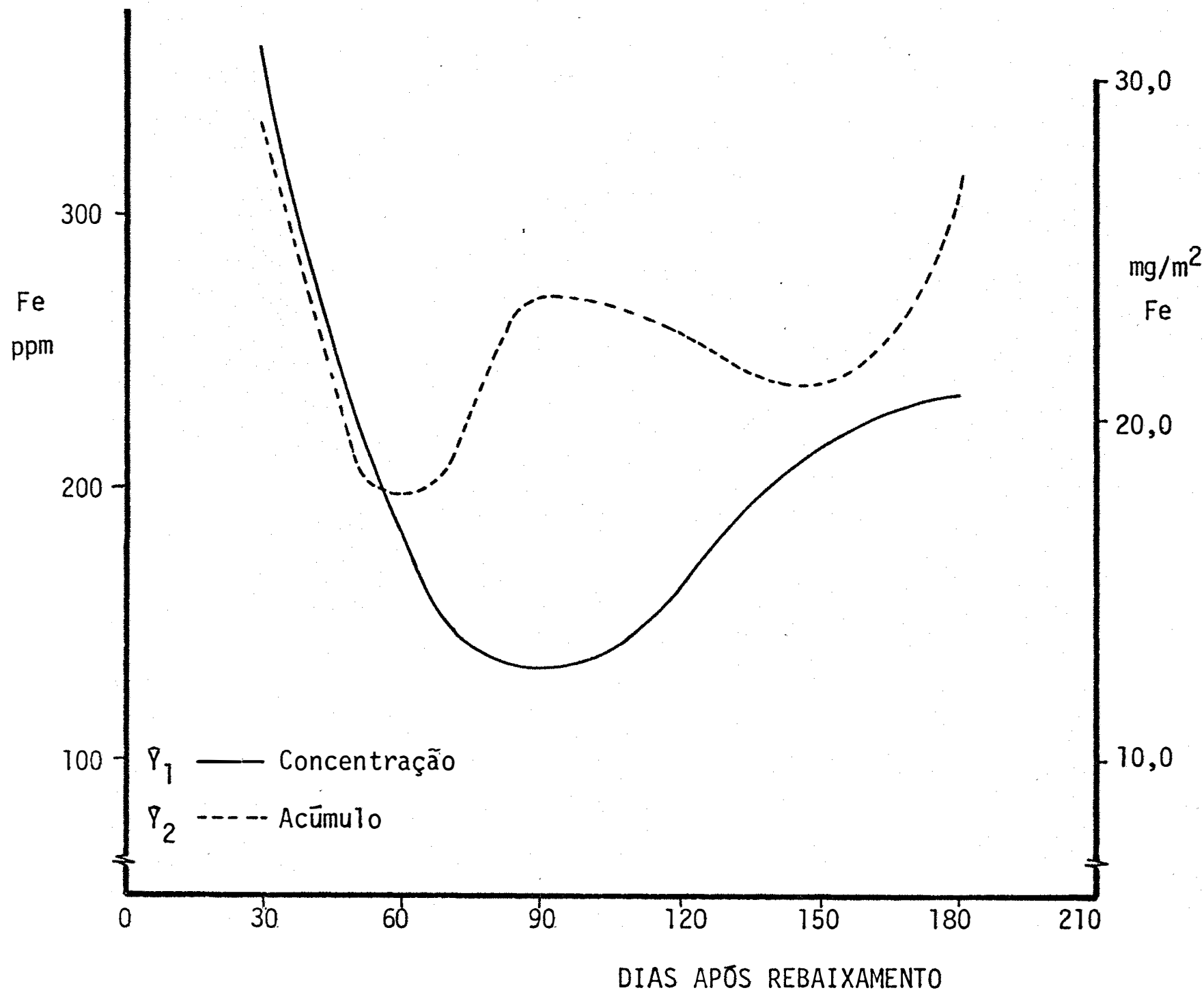

Figura 13 - Concentração e acúmulo de ferro (Y) da planta inteira de Panicum maximum Jacq. cr. Makueni, em fun ção da idade $(x)$. 
As diferenças nas concentracões de ferro são evidentes aos 30 dias, com $362,66 \mathrm{ppm}$, e aos 90 dias, com $136,22 \mathrm{ppm}$; nas demais idades estas diferencas são pouco expressivas.

observando a figura 13, verifica-se que as con centrações de ferro acham-se expressas por uma equação de regressão cūbica, decrescendo com uma tendēncia linear, atingin do a um ponto minimo aos 90 dias com 136,22 ppm, crescendo pos teriormente, ocasionando uma concentração de 236,25 aos 180 dias como mostra a tabela 5 .

SILVA et alii (1982) encontraram nos capins co lonião, angola e pangola teores médios desse nutriente na estação seca de 7,38 a 7,45 ppm e nas chuvas variaram de 8,67 a 9,21 ppm. GOMIDE et alii (1969) constataram através dos càpins napier, pangola, colonião, gordura e quicuio o teor de ferro varia de acordo com a espécie e decresce com a idade. Embora sejam escassas as informações à respeito dos niveis de ferro nas plantas forrageiras, citam-se alguns trabalhos como o de DE ALBA e DAVIS (1957), no Paraguai, em que foram obtidos niveis extremos de 90 a 770 ppm; GAVILLON (1963), no Rio Grande do Sul, obteve 94 a 98 ppm como concentracões mais baixas em pastagens nativas; Patel et alii (1966), citados por ANDREASI et alii (1968), encontraram amplitudes de variação entre 119 a 605 ppm em diversos tipos de plantas destinadas à alimentação dos animais. ANDREASI et alii (1968), em levantamento sobre elementos minerais em plantas 
forrageiras no Estado de São Paulo, verificaram que o capim gordura apresentou os mais elevados niveis médios de ferro - 494 ppm (na seca) e 415 ppm (nas águas), sendo que o colonião foi o que apresentou os teores mais baixos deste elemento - $119 \mathrm{ppm}$ (na seca) e $114 \mathrm{ppm}$ (nas àguas).

Dos teores obtidos por esses autores confrontados com os obtidos neste estudo, verifica-se que eles se en caixam nos niveis estabelecidos. As exigências de fe para novilhos em crescimento e em terminação são de 10 ppm de acordo com O NRC (1976). A partir de 400 ppm de Fe na dieta existe possibilidade de toxidez. Os teores obtidos no presente traba lho se encaixam dentro do nivel estabelecido. O teor mais baj xo (336 ppm de Fe) foi observado aos 120 dias, que é cerca de treze vezes às exigências de bovino em pastejo. 0 mais alto teor foi encontrado aos 30 dias $(362,66$ ppm) não surtindo efeitos tóxicos no metabolismo animal.

Com relação ao decréscimo do teor de ferro com - avanço da idade da planta, constata-se que as observacõesve rificadas até aos 90 dias concordam com a observação de GOMIDE et alii (1969), mas PERDOMO et alii (1977) nos capins pangola, guiné e estrela não observaram tendência definida no teor de ferro nos referidos capins, sendo verificado o mesmo neste trabalho.

Com relação às quantidades acumuladas de ferro, estas não diferiram significativamente com a idade, indicando 
um comportamento semelhante da planta inteira em cada idade quanto ao acúmulo do referido elemento. 


\section{CONCLUSOES}

5.1. Crescimento

A producão de matéria seca é māxima aos dias, com $1.425 \mathrm{~kg} / \mathrm{ha}$.

A maior velocidade de acúmulo de matéria seca ocorre próximo aos 60 dias após o rebaixamento.

5.2. Coeficiente de digestibilidade da matéria seca

0 coeficiente de digestibilidade da matéria se ca è máximo aos 30 dias com $51,9 \%$ e decresce aos 180 dias com 29,4\%. O coeficiente de digestibilidade da matéria seca diminui com a idade, sendo portanto vantajoso utilizar a graminea em idades mais jovens e a intervalos de corte maiores que 180 dias. 
5.3. Elementos minerais

5.3.1. Macronutrientes

5.3.1.1. Concentração

- A concentração de nitrogēnio é māxima aos 30

dias com $1,62 \%$ e minima aos 120 dias com $0,72 \%$.

- A concentração de fósforo é máxima aos 180 dias com 0,87\% e minima aos 60 dias com 0,003\%.

- A concentração de potāssio é linear com as idades variando de $2,82 \%$ na fase inicial a $0,76 \%$ aos 180 dias.

- A concentração de cárcio é máxima aos 90 dias, com $0,53 \%$.

- Não há variacão na concentracão de magnésio em função da idade da planta.

- A concentração de enxofre varia de $0,14 \%$ aos 30 dias para um minimo aos 120 dias com $0,07 \%$.

\subsubsection{Acūmulo}

- 0 acūmulo de fósforo, potássio e cālcio é má ximo aos 90 dias.

- O acūmulo de magnésio é máximo aos 120 dias.

- O acūmulo de enxofre é máximo aos 60 dias.

5.3.2. Micronutrientes

$5 \cdot 3 \cdot 2 \cdot 1$. Concentração 
- A concentracão de cobre ē mais elevada aos 30 dias com 7,63 ppm.

- A concientração de zinco é máxima aos dias com 22,66 ppm e minima aos 120 dias com 12,42 ppm.

- A concentração de boro à máxima aos 150 dias com 11,76 ppm e minima aos 60 dias com 1,69 ppm.

- A concentração de manganês é máxima aos 180 dias com 133,85 ppm e minima aos 30 dias com 49,64 ppm.

- A concentração de ferro é máxima aos 180 dias com 236,25 ppm e minima aos 90 dias com 136,22 ppm.

\subsubsection{Acūmulo}

- 0 acúmulo de cobre é máximo aos 90 dias.

- 0 acūmulo de zinco e ferro não diferiu nas diferentes idades.

- 0 acūmulo de boro e manganês é máximo aos 180 dias.

5.4. Exportação māxima de nutrientes correspondendo a $1.425 \mathrm{~kg}$ por hectare de matéria seca aos 120 dias de idade.

Potássio - 30,4 kg; nitrogênio - 13,9 kg; cālcio - 7,0 kg; magnésio - 6,3 kg; enxofre - 1,3 kg; fósforo $1,2 \mathrm{~kg}$; ferro - $286 \mathrm{~g}$; manganês - $157 \mathrm{~g}$; zinco - $23 \mathrm{~g}$; boro $13,2 \mathrm{~g}$ e cobre - 7,6 $\mathrm{g}$. 


\section{LITERATURA CITADA}

ACCIOLY, J.C., 1972. Teores de ferro, manganês, zinco, cobre e molibdēnio em gramineas e leguminosas, coletadas em Fortaleza, Cearā, Brasil. Cien. Agron., 2(1): 57 .

ADAMS, R.S., 1975. Simposium: New concept and development in trace elements nutrition. Variability in mineral and trace element content of dairy cattle feeds. J. Dairy Sci., 58: 1538 .

AGROCERES, 1982. Pastagens melhoradas. 0pcão para uma pecuāria lucrativa. São Paulo. 2ạ edicão. $23 p$.

ALBA, J. de e G.K. DAVIS, 1957. Minerals en la nutricion an mal en la América Latina. Turrialba, Costa Rica, 7: 16-33.

ANDREASI, F.; C.X. MENDONÇA JUNIOR; J.S.M. VEIGA; F. PRADO e R.C. BARNABE, 1966/1967. Levantamento dos elementos minerais em plantas forrageiras de āreas delimitadas do Estado de São Paulo. I. Cālcio, fósforo e magnnēsio. Rev. Soc. Med. e Vet. S.Paulo, $\underline{7}(3): 583-604$.

ANDREASI, F.; C.X. MENDONÇA JUNIOR; J.S.M. VEIGA E F. PRADO, 1968. Levantamento dos elementos minerais em plantas forrageiras de āreas delimitadas do Estado de São Paulo. III. Ferro e Manganēs. Rev. da Fac. de Med. e Vet. de São Paulo, $\underline{7}(4): 857-870$. 
ANDREASI, F.; C.X. MENDONCA JUNIOR; J.S.M. VEIGA e F. PRADO, 1969. Levantamento dos elementos minerais em plantas forrageiras de āreas delimitadas do Estado de São Paulo. IV. Zinco. Rev. Fac. Med. Vet. São Paulo, $\underline{8}(1):$ 177-190.

ASARE, E. 0., 1974. Dry Matter, chemical composition and nutritive value of buffel grass grown alone and in misture other tropical grasses and legumes. Proceedings of the 12 th International Grassland Utilization, 1, Moscow, USRR, p. $53-54$

BOSE, M.L.V., 1971. Composição em fibra bruta, celulose e lignina, digestibilidade da celulose in vitro e em C.E.D. dos capins colonião, gordura, jaraguá, napier, pangola em desenvolvimento vegetativo. Piracicaba, ESALQ/USP, 63 p. (Tese de Doutoramento).

BLUE, W.G. e L.E. TERGAS, 1969. Dry seasons deterioration of forage quality in the wet dry tropics. Soil and crop Sci. Soc. Fla. Proc., 29: 224 .

BRASIL. MINISTERIO DE AGRICULTURA, 1960. Levantamento e reco nhecimento dos solos do Estado de São Paulo. S.N.P.A. Bol. 12. $605 p$.

BUTERWORTH, M.D., 1962. Studies on pangola grass at ICTA-Trin dad: The digestibility of pangola grass at various stages of growth. Tropical Agriculture, 38: 187-193

CARRIEL, J.M., J.V. PEDREIRA, SilVEIRA e, H.B. MATTOS. 1974. Estimativa da ocorrēncia dos principais capins no Estado de São Paulo, Zootecnia, Nova Odessa, SP, 17(1): $5-25$

CIAT - Centro International de Agricultura Tropical, 1978. Produção de Pastagens em solos ācidos dos trópicos. SANCHES, P.A. e L.E. TERGAS (edit.). Proc. of a Seminar held at CIAT, Cali, Colombia. 488p. 
CHAPMANN, H.D. e P.F. PRATT, 1961. Methods for analys is for soils, plants and waters. Berkeley, University of California, Division of Agricultural Science, 7l-85.

CHAPMANN, H.D., 1966. In: "Diagnostic criteria for plants and soils (H.D. Chapmann, ed.), pp. 484-499. Univ. of California Press, Riverside.

CORSI, M., 1975. Adubação nitrogenada das pastagens. In: Anais do II Simpósio sobre Manejo da pastagem. Piracicaba, p.112-142.

CORSI, M., 1984. Ureia como fertilizante na produção de forragem. 2ọ Simpósio sobre Nutrição de Bovinos. Piracicaba, $44 p$.

ESCUDER, C.J., 1980. Utilização e manejo das pastagens tropi cais. Informe Agropecuārio, 6(70): 63-70.

FERNANDES, N.S. e A.M.H. SANTIAGO, 1972. Niveis de cobre em pastagens do Estado de Mato Grosso. 0 Biológico, 35: 358.

FIBGE - Fundação Instituto Brasileiro de Geografia e Estatisstica, 1980 - Anuārio Estatístico do Brasil Vol 41840 p. Rio de Janeiro.

GALLO, J.R.; R. HIROCE; O.C. BATAGLIA; P.R. FURLANI; A.M.C. FUR LANI; H.B. MATTOS; H.J. SARTANI E M.P. FONSECA, 1974. Composição química inorgânica de forrageiras do Estado de São Paulo. Bol. Ind. Animal, São Paulo, 31 (1): 115.

GAVILANES, C.C.; M.E. AL.ARCON e M.P. MENDOZA, 1978. Constitú yentes de la parede celular y digestibilidad del pasto bra quiaria (Brachiaria decumbens, Stapf.) em dos estados de desarol10. Revista I.C.A., Colombia, XIII(1): 91-98.

GAVILLON, 0., 1963. Levantamento da composição mineral das pastagens do Rio Grande do Sul. Rev. Fac. Agron. Vet. Porto Alegre, 6: 115-122. 
GAVILLON, 0. e A.T.F. QUADROS, 1976. O cobre, o molibdēnio e o sulfato inorgānico em pastagens nativas do Rio Grande do sul. Anuārio Téc: Inst. de Pesq. Francisco Osōrio, Porto. Alegre, 3: 423 .

GLADSTONES, J.S.; J.F. LONERAGAN, 1967. Mineràl elements in temperate crop and pasture plants. I. Zinc. Aust. J.Agric. Res., 18(3): 427-446.

GOMIDE, J.A.; C.H. NOLLER; G.O. MOTT; J.H. CONRAD E D.L. HILL, 1969. Mineral composition of six tropical grasses as influenced by plant age and nitrogen fertilization. Agron. J., Madison, Wisc., 6l(1): 120-3.

GOMIDE, J.A., 1976. Composição mineral de gramineas e leguminosas forrageiras tropicais. Simpósio Latinoamericano so bre pesquisa em nutrição mineral de ruminantes em pastagens. Belo Horizonte; p.20.

GOMIDE, J.A.; J.A. OBEID e J.F. TEIXEIRA NETO, 1979. Produtividade e valor nutritivo do capim colonião. Rev. da Soc. Bras. de Zootecnia, Viçosa, 8(2): 198-225.

GROF, B. e W.A.T. HARDING, 1970. Dry matter yields and animal production of guinea grass (Panicum maximum) on the humid tropical coast of North Queensland. Tropical Grass. land, $\underline{4}(1): 85-95$.

HAAG, H.P.; M.L. BOSE e R.G. ANDRADE, 1967. Absorção dos macronutrientes pelos capins colonião, gordura, jaraguá, napier e pangola. Anais da Escola Superior de Agricultura "Luiz de Queiroz", Piracicaba, 24: 177-188.

HARDING, H.A.T., 1972. The contribution of plant introduction to pasture development in the wet tropics of Queensland. Tropical Grasslands 6, 191-199. 
ITALIANO, E.C.; J.A. GOMIDE e P.H. MONNERAT, 1981. Influência de doses e modalidades de aplicação do superfosfato sim ples sobre o rendimento forrageiro e composição química do. capim jaraguá (Hyparrhenia rufa (Ness) Stapf). Rev. S.B.Z. $\underline{10}(1): 1-10$.

ITALIANO, E.C.; E. de MORAES e E.A. do C. CANTO, 1982b. Macronutrientes e F.T.E. em pastagens de capim colonião em degradação. Anais da XIX Reunião Anual da Sociedade Brasileira de Zootecnia, CNPq. Piracicaba. 467p.

JARDIM, W.R.; A.M. PEIXOTO e C.L. MORAES, 1962a. Composição mineral de pastagens na região de Barretos no Brasil Central. Piracicaba, ESALQ. 11p. (Boletim Técnico e Científi co, nọ 11).

JARDIM, W.R.; A.il. PEIXOTO e C.L. MORAES, 1962b. Observações sobre deficiencias minerais na nutrição de bovinos na região do Brasil Central. Piracicaba, ESALQ. 11p. (Bol. Tēc nico e Cienticico, nọ 11).

KOEPPEN, W., 1948. Climatologia. Trad. Pedro R. Hendriche Perez (Ed. Espanhola). Gräfica Panamericana, Buenos Aíres: 478p. (Original alemão).

LOURENÇO, A.J.; C.J. ESCUDER e N.M. RODRIGUES, 1980. Efeito da lactação na disponibilidade de forragens em pastagens de Brachiaria decumbens Stapf. Bol. Ind. Anin.. Nova Odessa, SP, 37(1): 47-58. 
MARTINEZ, H.E.P.; A.M.D. ALOISI e A.C.BOLIANI, 1984. 2. Macronutrientes em gramineas. In: "Nutrição mineral de forrageiras no Brasij". HAAG, H.P. (coord.). Fundação Car-. gill, Campinas-SP.

MCCOSKER, T.H. e J.K. TEITZEL, 1975. A review of guinea grass (Panicum maximum) for the wet tropics of Australia. Tropical Grasslands, $\underline{9}(3): 177-186$.

MENESES, J.B.O,S.; A.B. FERREIRA; R.I.J. HIPOLITO e G.A. DUSI, 1973. Contribuição ao estudo da digestibilidade aparente dos fenos dos capins pangola (Digitaria decumbens), Angola (Brachiaria mutica) e colonião (Panicum maximum) em diferentes estágios de desenvolvimento. Agronomia, 31: 51-56.

MIDDLETON, C.H. e McCOSKER, T.H., 1975. Makueni: a new guinea grass for North Queensland. Queenslands Journal of Agricul ture and Animal Sciences, 101: 351-355.

MIDDLETON, C.H., 1982. Dry matter and nitrogen changes in five tropical grasses as influenced by cutting height and frequency. Trop. Grass 1., 16(3): 112-117.

MINSON, D.J., 1971b. The digestibility and voluntary in take of six varieties of Panicum. Australian Journal of Experimental Agriculture and Animal Husbrandry, 2: 18-25.

MIRANDA, M.T., 1982. Crescimento e concentração de nutrientes em Panicum maximum cV. Makueni em função do fornecimen to de nitrogēnio, fósforo e potāssio. Piracicaba, ESALQ/ USP. 108p. (Tese de Doutoramento).

MITIDIERI, J., 1983. Manual de gramíneas e leguminosas para pastos tropi cais. São Paulo, Ed. da Universidade de São Paulo. 198p.

MONTEIRO, F.A.; J.C. WERNER, 1977. Efeitos das adubações nitrogenadas e fosfatadas em capim colonião, na formação e em pasto estabelecido. Bol. Ind. An., São Paulo, 34(1): 91-101. 
PEDREIRA, J.V.S. é J.J..N. SILVEIRA, 1972. Variação da composição bromatológica do capim colonião Panicum maximum Jaca. Bol. Ind. Animal, N.S., 29(1): 185-190.

PERDOMO, J.T.; R.L. SHIRLEY e C.F. CHICCO, 1977. Availability of nutrient minerals in form tropical forages fed freshly chopped to sheeps. Journal of Animal Science, Albany, 49 (5): 1114 .

PORZECANSKI, I., 1982. Melhoramento de plantas forrageiras como alternativa para adaptação a solos tropicais. In: Seminārios sobre Nutrição de Plantas Forrageiras em Solos Tro picais Ácidos. Campo Grande-MS, EMBRAPA-CNPGC. 98p.

PRÓSPERO, A.0. e A.M. PEIXOTO, 1972. Composição mineral do capim elefante (Pennisetum purpureum, Schum) variedade napier, em diferentes estádios de desenvolvimento. 0 Solo, Piracicaba, LXIX(2): 45-51.

REID, R.L.; A.J. POST; F.J. OLSEN e J.S. MUGERWA, 1973. Studies on the nutritional quality of grasses and legumes in Uganda. I. Application of in vitro digestibility techniques to species and stages of growth effects. Tropical agricultu re, London, 50: 1-15.

SANCHEZ, P.A., 1976. Properties and management of soils in the tropics. New York. Wiley Interscience Publications., $518 p$.

SANCHEZ, P.A. e R.F. ISBELL, 1982. Comparação entre os solos tropicais da América Latina e os da Austrālia. In: "Produ ção de Pastagens em Solos Ācidos do Trópicos". TERGAS, L. F.; SANCHEZ, P.A.; SERRAO, E.S. (ed.). Editerra Editorial. Brasilia, DF. 
NASCIMENTO JUNIOR, D.; F.C. da SILVA e J. dos SANTOS PINHEIR0, 1976. Teores de alguns minerais do capim jaragua (Hyparrhenia rufa (Ness) Stapf) em vārias idades de corte. Rev. Soc. Bras. Zoot., Viçosa, $\underline{5}(1): 48-55$.

N.R.C. - NATIONAL RESEARCH COUINCIL, 1970. Nutrient requirement of beef cattle nọ 4. Rev. ed. Washington, D.C. 55p.

N.R.C. - NATIONAL RESEARCH COUNCIL, 1976. Nutrient requirement of domestic animals no 4. Nutrient requirement of beef cattle. 5th ed. National Academy of Sciences, Washin gton, D.C.

N.R.C. - NATIONAL.RESEARCH COUNCIL, 1980. Nutrient requirements of dairy. cattle. 5 th ed. National Academy of Sciences, Washington, D.C.

OKADA, T., 1976. Agronomic characteristics of green panic, Panicum maximum var. trichoglume Eyles. Tropical Agriculture Research Series, London, 10(3): 138-142.

OLUBAJO, F.D.; P.J. VANOEST e V.A. OYENUGA, 1974. Comparision and digestibility of four tropical grasses grown in Nigeria. Journal of Animal Science, Albany, 38(1): 149-153.

ORELLANA, A.P.; H.P. HAAG, 1982. Nutrição mineral de ANdropogon gayanus Kunth. var. bisguamulatus (Hochst) Hack. I. Recrutamento de macronutrientes. Anais da E.S.A. "Luiz de Queiroz", Piracicaba, 39(1): 11-47.

OYENUGA, V.A., 1960. Effect of stage of growth and frequency of cutting on the yield and chemical composition of some Nigerian fodder grasses - Panicum maximum Jacq. Journal Agric. Sci., 55: 339-350. 
SARRUGE, J.R.eH.P. HAAG, 1974. Anālises em plantas, Piracicaba, Departamento de Química, ESALQ/USP. $56 \mathrm{p}$.

SEMPLE, A.T., 1970. Problemas e pesquisas em pastagens. In: Instituto de Zootecnia. Fundamentos de Manejo de Pastagens. 2. imp. São Paulo. p.113-131.

SILVA, J.F.C. da e J.A. GOMIDE, 1967. Efeito do estágio de maturação sobre o consumo e a digestibilidade da matéria seca de trēs gramineas tropicais. Rev. Ceres, 13(76): 225 -275. Viçosa, $M G$.

SILVA, G.N. da; M.0. MENDES e L.R. FREIRE, 1982. Teores de alguns nutrientes minerais em três gramineas forrageiras. Rev. Soc. Bras. Zoot., 11(1): 151-167.

SILVEIRA, A.C., 1970. Efeito da maturidade da planta e diferentes tratamentos sobre a digestibilidade in vitro de silagens de capim elefante, variedade napier (Pennisetum purpureum Schum.). Piracicaba, ESALQ/USP. 98p. (Dissert. Mest.)

SOUZA, J.C. de; J.H. CONRAD; W.G. BLUE e L.R. MCDOWELL, 1979. Interelaçẽes entre minerais no solo, plantas forrageiras e tecido animal. I. Cálcio e fósforo. Pesq. Agropec. Bras. $\underline{14}(4): 387-395$.

SOUZA, J.C. de; J.H. CONRAD, W.G. BLUE; C.B. AMMERMAN e L.R. MCDOWELL, 1981. Interrelações entre minerais no solo, plan tas forrageiras e tecido animal. 3. Manganés, ferro e cobalto. Pesq. Agropec. Bras., Brasilia, 16(5): 739-746.

TEITZEL, J.K., 1969a. Pastures for the wet tropical coast. Queensland Agricultural Journal, 95: 304-311. 
TEITZEL, J.K., 1969b. Pastures for the wet tropical coast. Queensland Agricultural Journal, 95: 464-7.

TEITZEL, J.K.; R.A. ABBOTTEW. MELLOR, 1974b. Beef cattle pas ture in wet tropics. Queensland Agricultural Journal, 100: $185-189$.

TEIXEIRA, T.; J. CAMPOS; J.M. BRAGA; D.J. da SILVA, 1971. Deficiēncia de fōsforo, cobre e cobalto em pastagem do municīpio de Morrinhos, Goiās. Experientiae, Viçosa, 12 (3): 63.

TINNIMIT, P., 1974. Forage avaluation using various laboratory techniques. East Lansing, Michigan State University; (Ph.D. Thesis).

UNDERWOOD, E.J., 1962. Trace elements in human and animalnutrition. 2.ed. New York, Academic Press, 429p.

UNDERWO0D, E.J., 1968. Los minerales en la alimentacion del ganado. FAO. Zaragosa, Editorial Acribia, $320 \mathrm{pp.}$

USBERTI FILHO, J.A., 1982. Tobiatã, nova cultivar de capim colonião. Casa da Agricultura nọ 1, pp.2 Separata, Edita da pela CATI.

VAN SOEST, P.J., 1975. Composition and nutritive value of forages. In: Edited by HEALTH, M.; D.S. METCALF e R. F. BARNES. Forage: The Science of Grassland Agriculture, $3^{\text {rd }}$ Edition, 3rd Printing, 1975. U.S.A., 135-147.

VAN SOEST, P.J.; S.D.R. MERTENS E D. DEINOM, 1978. Preharvest factors influencing quality of conserved forages. Journal Animal Science, U.S.A., 47(3): 713-720. 
VICENTE-CHANDLER, J. e J.FIGARELLA, 1962. Effects of five nitrogen sources yield and composition of Napier grasses. J.Agron. Un. Porto Rico, 46(2): 101-106.

VIEIRA, J.D., 1979. Produção de matéria seca, coeficiente dé digestibilidade e concentração de nutrientes no capim colo nião (Panicum maximum Jacq.) em função dos cortes aos. 30, 45, 60 e 75 dias. Piracicaba, ESALQ/USP. 71p. (Disserta ção de Mestrado).

WARD, G.M., 1966. Potassium metabolism of domestic ruminants a review. Journal of Dairy Science, Champaign, III; 49 (3): 268-277.

WERNER, J.C. e H.P. HAAG, 1972. Estudos sobre a nutrição mineral de alguns capins tropicais. Bol. Ind. Animal, S.P. N.S., 29(1): 191-245. 